\title{
Valproic acid enhances the efficacy of radiation therapy by protecting normal hippocampal neurons and sensitizing malignant glioblastoma cells
}

\author{
Dinesh Thotala ${ }^{1,4}$, Rowan M. Karvas ${ }^{1}$, John A. Engelbach ${ }^{3}$, Joel R. Garbow ${ }^{2,3,4}$, \\ Andrew N. Hallahan ${ }^{1}$, Todd A. DeWees ${ }^{1}$, Andrei Laszlo ${ }^{1}$, Dennis E. Hallahan ${ }^{1,3,4,5}$ \\ ${ }^{1}$ Department of Radiation Oncology, Washington University in St. Louis, Missouri, USA \\ ${ }^{2}$ School of Medicine, Washington University in St. Louis, Missouri, USA \\ ${ }^{3}$ Mallinckrodt Institute of Radiology, Washington University in St. Louis, Missouri, USA \\ ${ }^{4}$ Siteman Cancer Center, Washington University in St. Louis, Missouri, USA \\ ${ }^{5}$ Hope Center, Washington University in St. Louis, Missouri, USA \\ Correspondence to: \\ Dennis E. Hallahan, e-mail: dhallahan@radonc.wustl.edu \\ Keywords: valproic acid (VPA), neuroprotection, histone deacetylase (HDAC), radioprotection, cancer therapy \\ Received: May 29, $2014 \quad$ Accepted: September 04, $2015 \quad$ Published: September 16, 2015
}

\section{ABSTRACT}

Neurocognitive deficits are serious sequelae that follow cranial irradiation used to treat patients with medulloblastoma and other brain neoplasms. Cranial irradiation causes apoptosis in the subgranular zone of the hippocampus leading to cognitive deficits. Valproic acid (VPA) treatment protected hippocampal neurons from radiationinduced damage in both cell culture and animal models. Radioprotection was observed in VPA-treated neuronal cells compared to cells treated with radiation alone. This protection is specific to normal neuronal cells and did not extend to cancer cells. In fact, VPA acted as a radiosensitizer in brain cancer cells. VPA treatment induced cell cycle arrest in cancer cells but not in normal neuronal cells. The level of antiapoptotic protein Bcl-2 was increased and the pro-apoptotic protein Bax was reduced in VPA treated normal cells. VPA inhibited the activities of histone deacetylase (HDAC)

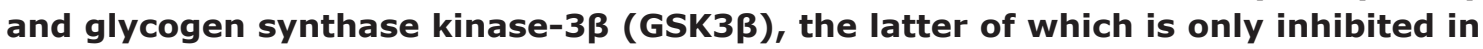
normal cells. The combination of VPA and radiation was most effective in inhibiting tumor growth in heterotopic brain tumor models. An intracranial orthotopic glioma tumor model was used to evaluate tumor growth by using dynamic contrast-enhanced magnetic resonance (DCE MRI) and mouse survival following treatment with VPA and radiation. VPA, in combination with radiation, significantly delayed tumor growth and improved mouse survival. Overall, VPA protects normal hippocampal neurons and not cancer cells from radiation-induced cytotoxicity both in vitro and in vivo. VPA treatment has the potential for attenuating neurocognitive deficits associated with cranial irradiation while enhancing the efficiency of glioma radiotherapy.

\section{INTRODUCTION}

Radiotherapy, the clinical application of ionizing radiation, is a crucial treatment option in modern cancer therapy in addition to surgery and systemic therapy. This is corroborated by the fact that more than $60 \%$ of all cancer patients receive radiotherapy $[1,2]$. Cranial irradiation is commonly used for the treatment of neoplasms involving the central nervous system. Radiotherapy can have negative sequelae of acute neurocognitive deficits, especially in the pediatric population [3-5]. The pathogenesis of radiation-induced neurocognitive deficits involves apoptosis of neuroproliferative cells in the subgranular zone of the hippocampus, a region in the brain vital for learning and memory [6-11]. Several studies have demonstrated a steep, long-term decline in 
subgranular neurogenesis in the dentate gyrus following radiation exposure [11-15] and direct irradiation of the hippocampus has been shown to result in pronounced cognitive deficits [16]. The cognitive deficits following hippocampal irradiation include deficits of learning, memory, and spatial processing $[17,18]$. Other areas of the cerebrum appear to be less sensitive to the effects of radiation [19]. Although at present there is no pharmacological prophylaxis available for the prevention of radiation-induced neurocognitive deficits, the drugs memantine and minocycline are promising novel agents. Memantine attenuated cognitive function decline after whole brain radiotherapy (WBRT) in patients with brain metastases [20]. Minocycline ameliorated cognitive impairment induced by WBRT in animal models [21].

Valproic acid (VPA) is a short branched-chain carboxylic acid that is an FDA approved anti-seizure and antidepressant drug that is well tolerated and whose toxicity profile has been extensively characterized [22]. VPA has a neuroprotective effect in the setting of various neurological insults, including ibetinoic acid [23], glutamate toxicity [24, 25], intracerebral hemorrhage [26], ischemia [27, 28], malonate toxicity [29], and oxidative stress [30]. The inhibition of histone deacetylase (HDAC) activity by VPA is thought to be involved in such neuroprotection [24-27, 31-34]. VPA inhibits both class I and II HDACs with resultant hyperacetylation of histone $\mathrm{H} 3$ and $\mathrm{H} 4$ [35-39]. In addition to HDAC inhibition, VPA has been shown to have effects on the Akt/GSK3 $\beta$ pathway, an observation that provides a novel facet of mechanisms involved in the neuroprotective effects of VPA [40]. Other pathways have also been proposed, including the induction of alphasynuclein [24], heat shock protein 70 [34], brain-derived neurotrophic factor [41], and modulation of the JNK pathway [42].

In addition to protecting healthy neurons, treatment with VPA can selectively kill various cancer cell lines including glioblastoma [43-45], erythroleukemic cells [43], colon cancer cells [46] and prostate cancer cells [47]. The preclinical data of VPA on 19 different types of solid cancers including glioma have been summarized [48, 49]. The mechanism of sensitization is proposed to involve inhibition of HDAC leading to interference with the repair of double strand DNA breaks [50-53]. VPA is also known to inhibit cell growth in cancer cells by inducing apoptosis and cell cycle arrest $[54,55]$.

GBM patients treated with VPA as an anticonvulsant agent during treatment with radiochemotherapy have recently drawn attention because of better outcomes of the treatment, reviewed in [56]. Combined therapy with VPA produced a 3-month longer overall survival (OS) as compared with carbamazepine in patients with GBM [57]. Several recent studies have found improved OS in both children and adults, ranging from 3-6 months by the inclusion of VPA [48, 58-61]. It has been speculated that the HDAC inhibitory properties of VPA could mediate the prolonged survival derived from radio-chemotherapy seen in GBM patients [62].

Whole genome expression monitored by microarray analysis of primary tumors of patients treated with VPA showed significant up-regulation of hundreds of genes belonging to multiple pathways. These include ribosomal proteins, oxidative phosphorylation, MAPK signaling, focal adhesion, cell cycle, antigen processing and presentation, proteasome, apoptosis, PI3K, Wnt signaling, calcium signaling, TGF-beta signaling, and ubiquitinmediated proteolysis among others [49].

In the present study, we found that VPA protected the normal hippocampus from radiation-induced damage, while sensitizing malignant gliomas to radiation. We analyzed the anti-apoptotic effects of VPA administration in vitro and in vivo and characterized the changes in intracellular signaling and protein expression induced by administration of VPA prior to radiation. We also determined the radiosensitizing effect of VPA in glioblastoma cell lines, and its effects on tumor growth delay and survival of intracranial glioma-bearing mice using dynamic contrast enhanced magnetic resonance imaging, DCE MRI.

\section{RESULTS}

\section{VPA treatment protects hippocampal neurons from radiation-induced apoptosis in vivo}

To determine whether VPA regulates cell survival and apoptosis in the subgranular zone of the hippocampus after irradiation, we pretreated 1-week-old mice with $300 \mathrm{mg} / \mathrm{kg}$ of VPA for 7 days prior to cranial irradiation with 7Gy. Typically, glioblastoma patients are treated with fractionated focal irradiation delivered as daily fractions of 2 Gy given five days per week for 6 weeks, for a total of 60 Gy [63]. We have shown that treatment with 7 Gy is in the steep part of the sigmoidal dose response curve for radiation-induced apoptosis in the mouse hippocampus [64] and hence we used 7 Gy for our studies. Apoptosis within the subgranular zone was determined by staining the hippocampal sections with a TUNEL kit, and the TUNEL positive cells (TPC) were counted (Figs. 1A $\&$ 1B). Three sections from each of three different mice in each treatment (a total of 9 sections per treatment) were analyzed. Mice irradiated with 7Gy had increased apoptosis compared to untreated mice. Mice treated with VPA prior to $7 \mathrm{~Gy}$ irradiation had significantly fewer TPC compared to mice irradiated with 7 Gy $(P<0.001$; Fig. 1B), indicating that VPA treatment protected the mouse hippocampus from radiation-induced apoptosis.

\section{VPA treatment attenuates radiation-induced apoptosis in HT22 cells}

We monitored radiation-induced apoptosis in vitro by staining irradiated normal hippocampal HT22 cells with Annexin V-APC and propidium iodide. The stained 
A
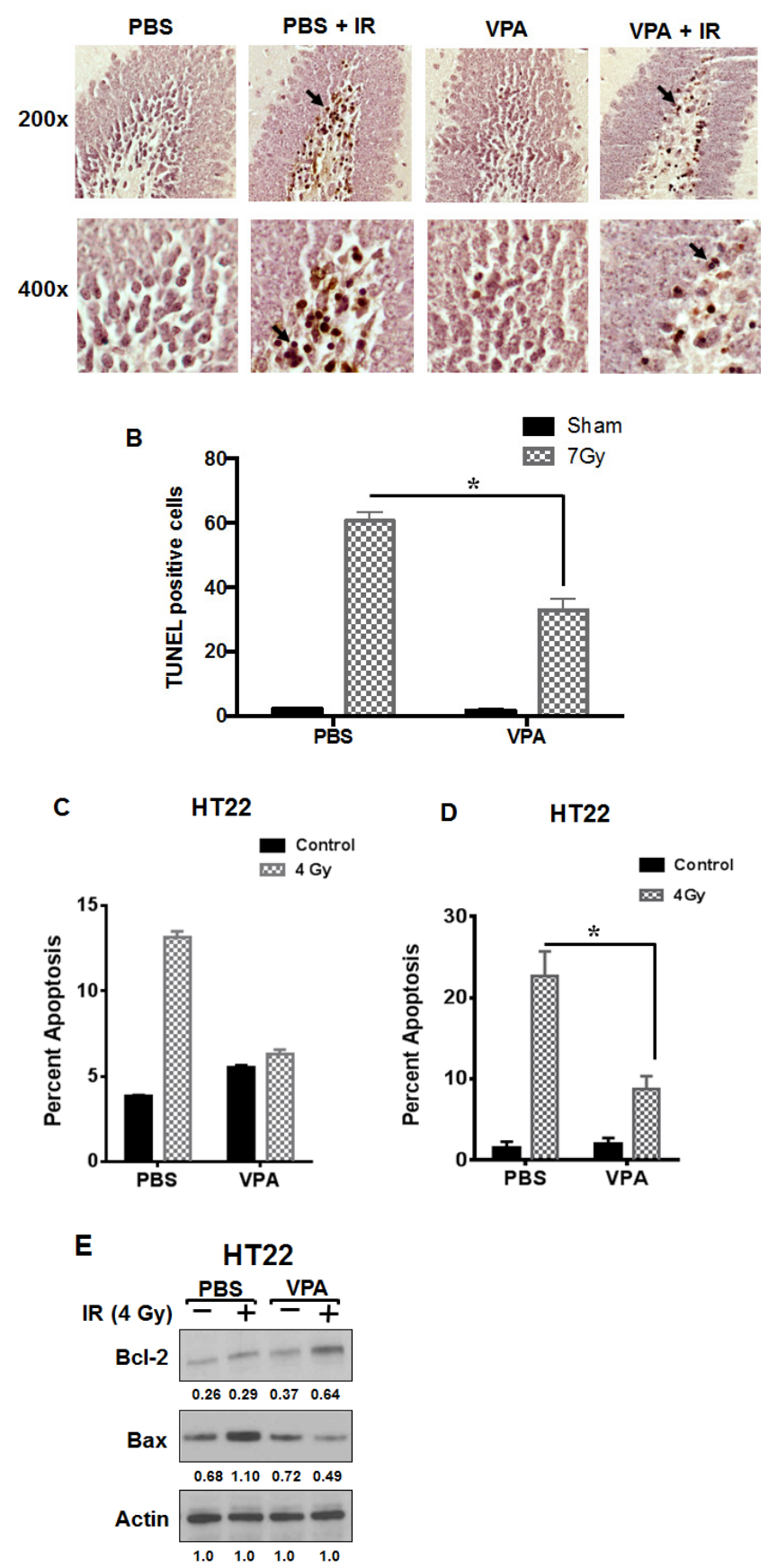

Figure 1: VPA treatment protects hippocampal neurons from radiation-induced apoptosis in vivo and modulates the expression of apoptotic signaling proteins in vitro. A. One-week-old C57BL/6 mice pups were treated with daily i.p. injections of VPA $(300 \mathrm{mg} / \mathrm{kg}$ ) or PBS for 7 days. One hour after the last VPA treatment, the pups heads were irradiated with $7 \mathrm{~Gy}$ while the rest of the body was shielded with lead. Twenty-four hours later, the animals were sacrificed and brains were fixed and coronally sectioned. Sections that contained hippocampus were stained with TUNEL. Shown are representative photographs of mouse hippocampus. The arrows indicate examples of TUNEL positive cells (TPC). B. Eight HPF at 200x magnification were evaluated and TPC were counted for each experimental group. Shown is the average number of TPC per HPF for each radiation dose group (SD of three independent experiments, ${ }^{*} P<0.05$ ). C. HT22 cells were treated with PBS or $0.6 \mathrm{mM}$ VPA for 7 days prior to irradiation with $4 \mathrm{~Gy} .24 \mathrm{~h}$ after irradiation, cells were stained with Annexin V-APC/propidium iodide and analyzed by flow cytometry; $* P<0.05$ D. Cells were fixed and stained with DAPI, and apoptotic cells were counted in eight randomly selected HPF at 200X magnification. Shown are bar graphs of the average percent of apoptotic cells for each treatment with SD from three experiments; ${ }^{*} P<0.05$. E. HT22 cells were treated with PBS or $0.6 \mathrm{mM}$ VPA for 7 days prior to irradiation with $4 \mathrm{~Gy}$. Whole cell extracts were immunobloted to determine the levels of Bax and Bcl-2. Actin was used to normalize the protein loading in each lane. Densitometry values representing the ratio of the various proteins normalized actin is indicated below each immunoblot. 
cells were analyzed by flow cytometry after various experimental treatments (Fig. 1C). Cells pre-treated with VPA prior to 4Gy irradiation had significantly less apoptotic cells $(12 \%$ annexin $\mathrm{V}$ positive: $P=0.002)$, than cells treated with PBS alone (50\%; Fig. 1C). To further confirm these results, we monitored the nuclear morphology of irradiated cells using DAPI staining (Supplemental Fig. 1, Fig. 1D). Pre-treatment of irradiated HT22 cells with VPA led to a protective effect, with a reduced number of apoptotic cells $(15 \%)$ compared to $35 \%$ in PBS-pretreated cells $(P<0.001$; Fig. 1D). We did observe a slight increased apoptosis when cells were treated with VPA when compared to PBS; this however was not statistically significant. Treatment of HT22 cells with VPA led to decreased levels of the pro-apoptotic protein BAX and increased levels the anti-apoptotic protein Bcl-2 (Fig. 1E), which is consistent with the results obtained using the other endpoints for apoptosis described above. However, we did not detect any PARP cleavage in irradiated HT22 cells as has been reported before (Supplementary Fig. 2) [65].

\section{VPA treatment reduces GL261 cell survival}

To determine the effect of VPA treatment on cell viability and survival of hippocampus-derived HT22 cells and glioblastoma GL261 cells, we performed a colony formation assay. Cells were treated with $0.6 \mathrm{mM}$ VPA or PBS for 7 days and equal numbers of cells were plated to determine plating efficiency. There was no significant difference in the numbers of colonies from HT22 cells treated with VPA $(P=0.398)$ compared to PBS treated cells (Fig. 2A). However, treatment of GL261 cells with VPA led to a significant decrease in colony formation $(P=<0.001)$ compared to PBS control (Fig. 2A).

\section{VPA treatment protects HT22 cells from radiation while sensitizing Daoy, D54 and GL261 cells}

To determine the effect of VPA treatment on the cellular response to radiation, we performed clonogenic cell survival assays. Pretreatment of hippocampus-
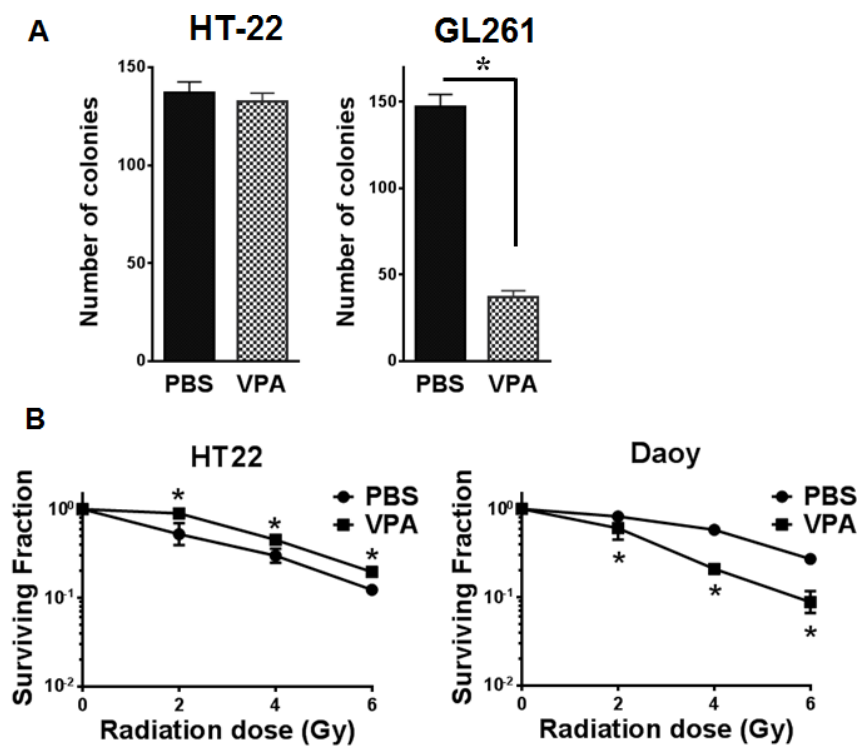

D54
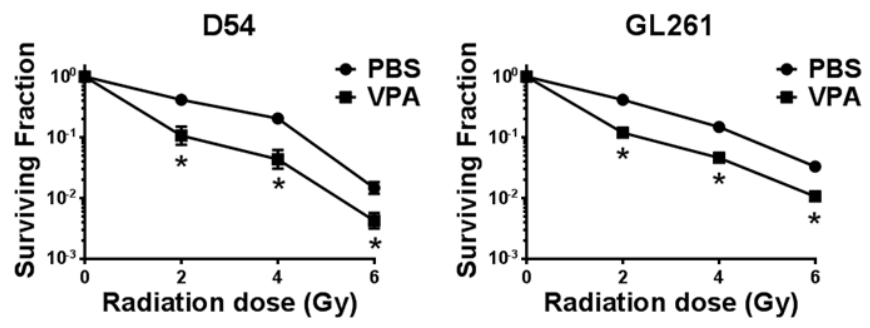

Figure 2: VPA acts as a radioprotector in normal cells and radiosensitizer in cancer cells. A. Equal numbers of HT22 or GL261 cells were plated for colony formation assay after treating with PBS or 0.6 mM VPA for 7 days. Plates were stained with $1 \%$ methylene blue after 10 days and colonies were counted. Shown are bar graphs depicting the number of colonies for each treatment with SD from three experiments; $* P<0.05$. B. HT22, Daoy, D54 and GL261 cell were treated with PBS (•) or 0.6 mM Valproic acid (घ) for 7 days followed by irradiation with $0,2,4,6$ or 8 Gy and plated for clonogenic survival assay. Shown are the surviving fractions and the SD from three experiments; $* P<0.05$.

(Continued) 

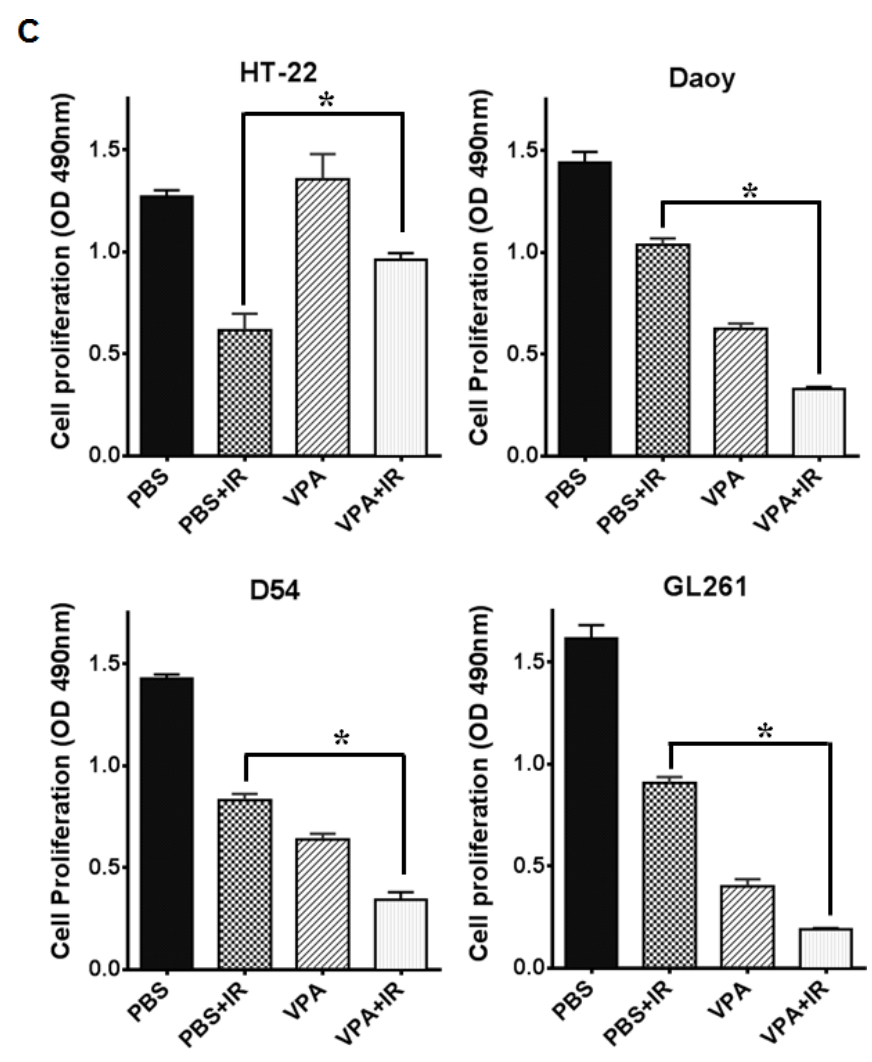

Figure 2: (Continued) C. Equal numbers of HT22, Daoy, D54 and GL261 cells were plated in 96-well plates after treatment with PBS or $0.6 \mathrm{mM}$ VPA for 7 days and then irradiated with $4 \mathrm{~Gy}$. After $96 \mathrm{~h}$, the cell viability was determined using a colorimetric cell proliferation assay. Shown are the absorbances at $490 \mathrm{~nm} ; * P<0.05$

derived HT22 cells with $0.6 \mathrm{mM}$ VPA for 7 days significantly abrogated radiation-induced cell killing (2Gy $P=0.040,4$ Gy $P=0.016,6$ Gy $P=0.060,8$ Gy $P=0.002$ ) as compared to cells treated with radiation alone with a $\mathrm{DMF}_{10}$ of 0.87 (Fig. 2B). However, pretreatment of Daoy (human medulloblastoma), D54 (human glioma) and GL261(mouse glioma) cells with $0.6 \mathrm{mM}$ VPA for 7 days prior to irradiation led to significant radiosensitization with $\mathrm{DMF}_{10}$ of 2.25, 1.49, and 2.31 for Daoy, D54 and GL261 cells, respectively (Fig 2B). These results indicate that VPA treatment protects normal hippocampal neuronal cells (HT22) from radiation induced cell killing, while radiosensitizing medulloblastoma cells (Daoy) and GBM cells (D54 \& GL261).

\section{VPA treatment inhibits Daoy, D54 and GL261 cell proliferation}

Having observed radiosensitization of cancer cells (Daoy, D54 and GL261) and radioprotection of normal cells (HT22) after VPA treatment in clonogenic assays, we wanted to ascertain if this was due to alterations in cell proliferation. HT22, Daoy, D54 and GL261 cells were treated with PBS or VPA $(0.6 \mathrm{mM})$ for 7 days and then equal numbers of treated cells (of each cell line) were plated in 96-well plates. The plates were then incubated for $96 \mathrm{~h}$, and then $20 \mu \mathrm{L}$ of cell proliferation assay reagent (Promega) was added. HT22 cells treated with VPA did not show any differences in proliferation compared to PBS treated cells $(P=0.065$; Fig. $2 \mathrm{C})$. However, treatment with VPA led to reduced cell proliferation in Daoy cells $(P=<0.002)$, D54 cells $(P=<0.001)$ and GL261cells $(P=<0.001$; Fig. 2C). Thus the anti-proliferative effect of VPA treatment was observed only in cancer cells (Daoy D54 and GL261) and not in normal neuronal cells (HT22).

\section{VPA treatment induces the accumulation of GL261 cells at $G_{2} / M$}

Since VPA treatment led to inhibition of cell proliferation only in cancer cells, we compared the effect of VPA treatment on the cell cycle distribution of normal vs. cancer cells. HT22 and GL261 cells were treated with PBS or VPA $(0.6 \mathrm{mM})$ for 7 days prior to irradiation with $4 \mathrm{~Gy}$. The cells were harvested $24 \mathrm{~h}$ post irradiation, stained with propidium iodide and analyzed by flow cytometry. There were no significant alterations of cell cycle distribution in HT22 cells treated with VPA alone, while irradiation led to the accumulation of cells in the $\mathrm{G}_{2} / \mathrm{M}$ phase (40\%) compared to untreated PBS controls $(18 \% ; P=<0.001)$. The accumulation in $\mathrm{G}_{2} / \mathrm{M}$ was abrogated when cells were treated with VPA $(25 \%)$ 
prior to irradiation ( $P=<0.001$; Fig. 3). Significant accumulation in the $\mathrm{G}_{2} / \mathrm{M}$ phase $(41 \%)$ was observed in GL261 cells treated with VPA when compared to untreated PBS control cells $(24 \%)(P=<0.001)$. A larger fraction of $\mathrm{G}_{2} / \mathrm{M}$ accumulation was observed when they were treated with a combination of VPA and irradiation with 4Gy (37\%) compared to irradiation alone $(28 \% ; P=<0.001)$. This increase was however not statistically significant from the G2/M accumulation induced by VPA treatment alone (40\%; Fig. 3). There was no major effect in the fraction of $\mathrm{S}$ phase cells in either cell line after the various experimental treatments.

\section{VPA treatment inhibits both HDAC and GSK3ß in $\mathrm{HT} 22$ cells}

VPA inhibits the activity of histone deacetylases, HDACs, most likely by binding to the catalytic center of the enzyme [35]. VPA has also been reported to inhibit the activity of glycogen synthase kinase 3 beta (GSK3 $\beta$ ) both in vitro $[66,67]$ and in vivo [67]. To determine if HDAC activity was inhibited by VPA treatments of HT22 and GL261 cells we monitored the levels of acetylated histone H4. To determine if VPA treatment inhibits GSK3 $\beta$ in HT22 hippocampal neurons and GL261 glioblastoma cells, we monitored the phosphorylation of GSK3 $\beta$ at ser9 that inhibits its activity and evaluated the levels of $\beta$-catenin as a surrogate indicator of GSK3 $\beta$ activity. Since active GSK3 $\beta$ phosphorylates $\beta$-catenin that promotes its degradation, increased accumulation of $\beta$-catenin correlates with decreased activity of GSK3 $\beta$. Inhibition of HDAC activity was observed in both HT22 and GL261 cells treated with $0.6 \mathrm{mM}$ VPA for 7 days (Fig. 4). Interestingly, the inhibition of GSK $3 \beta$ by VPA treatment was observed only in HT22 cells and not in GL261cells (Fig. 4). These results indicate that VPA, in addition to inhibiting HDAC, also inhibits GSK3 $\beta$ in HT22 cells but not in GL261cells. Thus, the overall mechanisms of the action of VPA are different in these two cell lines. VPA treatment associated inhibition of GSK $3 \beta$ activity contributed to reduced radiationinduced apoptosis in HT22 cells (Fig. 1C). We have previously shown that inhibition of GSK3 $\beta$ either with small molecule inhibitors or knockdown led to decreased apoptosis in normal hippocampal neurons and normal epithelial cells [64, 68, 69].

\section{VPA treatment represses tumor growth in irradiated GL261 and D54 mouse tumor models}

To determine the in vivo efficacy of VPA, two heterotopic glioma models GL261 (mouse) and D54 (human) were used to generate tumor growth delay

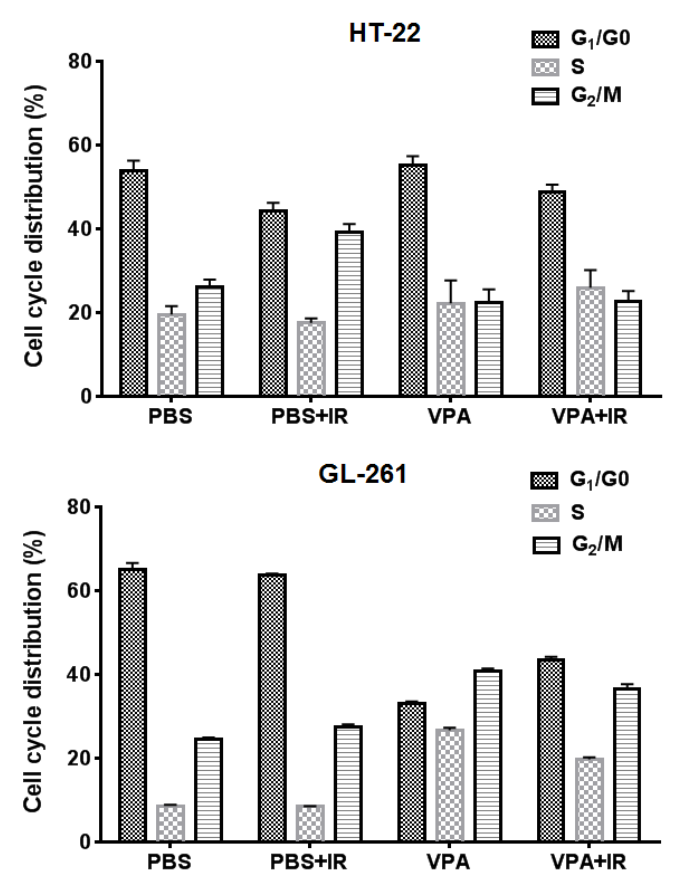

Figure 3: VPA treatment induces G2/M accumulation in cancer cells. HT22 cells and GL261 cells were treated with PBS or $0.6 \mathrm{mM}$ VPA for 7 days prior to irradiation with $4 \mathrm{~Gy} .24 \mathrm{~h}$ after irradiation, cells were collected, fixed and stained with PI and cell cycle distributions were determined by flow cytometry. Shown are the bar graphs of the average change in the fraction of $G_{1} / G_{0}, S$ and $G_{2} / M$ phase cells after each treatment. 


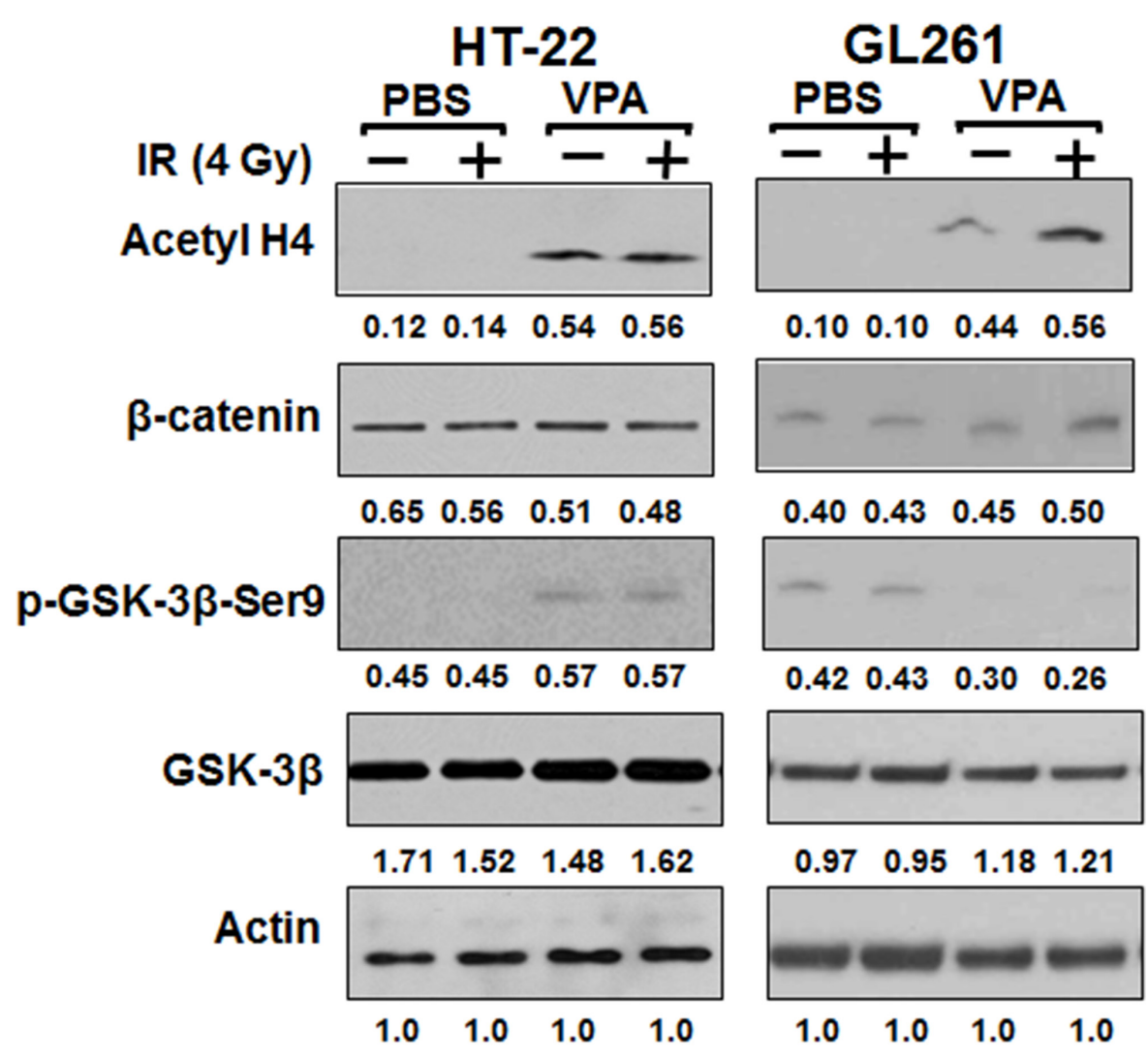

Figure 4: VPA inhibits both HDAC and GSK3ß in normal cells, but only HDAC in cancer cells. HT22 and GL261 cells were treated with $0.6 \mathrm{mM}$ VPA for 7 days prior to irradiation with $4 \mathrm{~Gy}$. Total cellular proteins were immunobloted using antibodies against $\beta$-catenin, p-GSK3 $\beta$ (Ser9), GSK3 $\beta$ and Acetyl H4 to determine their levels. A representative (from 3 repeats) immunoblot is shown.

curves (Fig. 5A \& 5D). One million GL261 or D54 cells were injected subcutaneously in the right hind limb of nude mice. Tumor-bearing mice were then treated with PBS alone, irradiation alone (five daily fractions of $2 \mathrm{~Gy})$, VPA (300 mg/kg) alone for 5 days, or VPA $(300 \mathrm{mg} / \mathrm{kg}$ ) for 5 days followed by irradiation (five daily fractions of $2 \mathrm{~Gy}$ ). In studies on the effect of VPA in mice models, doses ranging from $150 \mathrm{mg} / \mathrm{Kg}$ to $400 \mathrm{mg} / \mathrm{Kg}$ have been used $[49,67,70]$. The time required to reach a tumor volume of $0.6 \mathrm{~cm}^{3}$ was determined (Fig. 5B $\& 5 \mathrm{E}$ ). An average of 13 days (GL261) and 10.2 days (D54) was required to reach this tumor volume in PBS treated mice, 20 days (GL261) and 12 days (D54) in the VPA treated mice, 26.5 days (GL261) and 15.2 days (D54) days in irradiated mice and 36.5 days (GL261) and 24 days (D54) in mice treated with combination of VPA and irradiation. Kruskal-Wallis and Tukeys pairwise comparisons indicated a significant difference in the number of days required to reach a tumor volume of $0.6 \mathrm{~cm}^{3}$ between each treatment group (Figs $5 \mathrm{~B} \& 5 \mathrm{E}$ ). We also analyzed the effect of the treatments on mean tumor growth at the midpoint (the $15^{\text {th }}$ day) of the study (Fig. 5C \& 5F). The most pronounced tumor growth delay was observed in tumors receiving a combination of VPA and irradiation $\left(0.17 \mathrm{~cm}^{3}\right.$ in GL261; $0.38 \mathrm{~cm}^{3}$ in D54), followed by tumors treated with irradiation alone $\left(0.34 \mathrm{~mm}^{3}\right.$ in GL261; $0.65 \mathrm{~cm}^{3}$ in D54), followed by tumors treated with VPA alone $\left(0.43 \mathrm{~cm}^{3}\right.$ in GL261; $0.84 \mathrm{~cm}^{3}$ in D54) followed by untreated tumors $\left(0.86 \mathrm{~cm}^{3}\right.$ in GL261; $1.06 \mathrm{~cm}^{3}$ in D54). This tumor growth data from day 15 was also analyzed using Kruskal-Wallis and Tukeys pairwise comparisons. The growth of both GL261 and D54 tumors was significantly delayed in mice treated with the combination of VPA and irradiation when compared to mice receiving radiation alone $(P=<0.001)$, or mice receiving VPA alone $(P=<0.001)$, or PBS treated controls $(P=<0.001)$. Tumor growth was also significantly delayed in mice treated with VPA alone when compared to untreated control tumors $(P=<0.001)$.

\section{VPA treatment in combination with irradiation reduces intracranial tumor growth}

Magnetic resonance imaging, MRI, provides detailed information about the anatomy and morphology of brain-tumors, enabling effective diagnosis and treatment. We used dynamic contrast-enhanced magnetic resonance (DCE MRI) techniques to image the effects of VPA on tumor growth in an orthotopic intracranial 


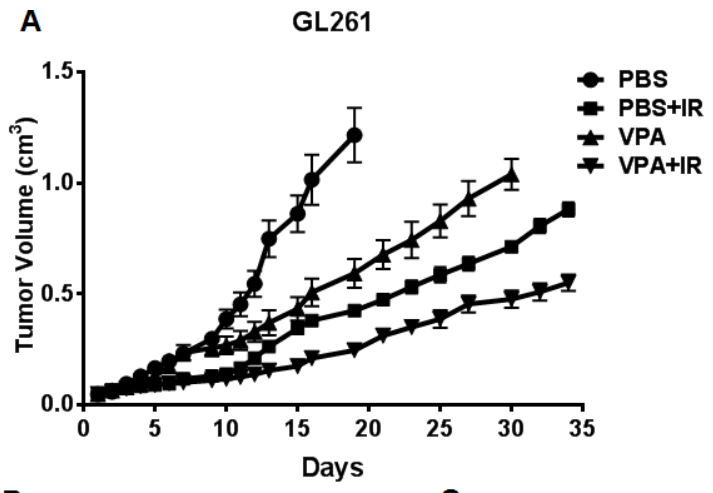

B

C
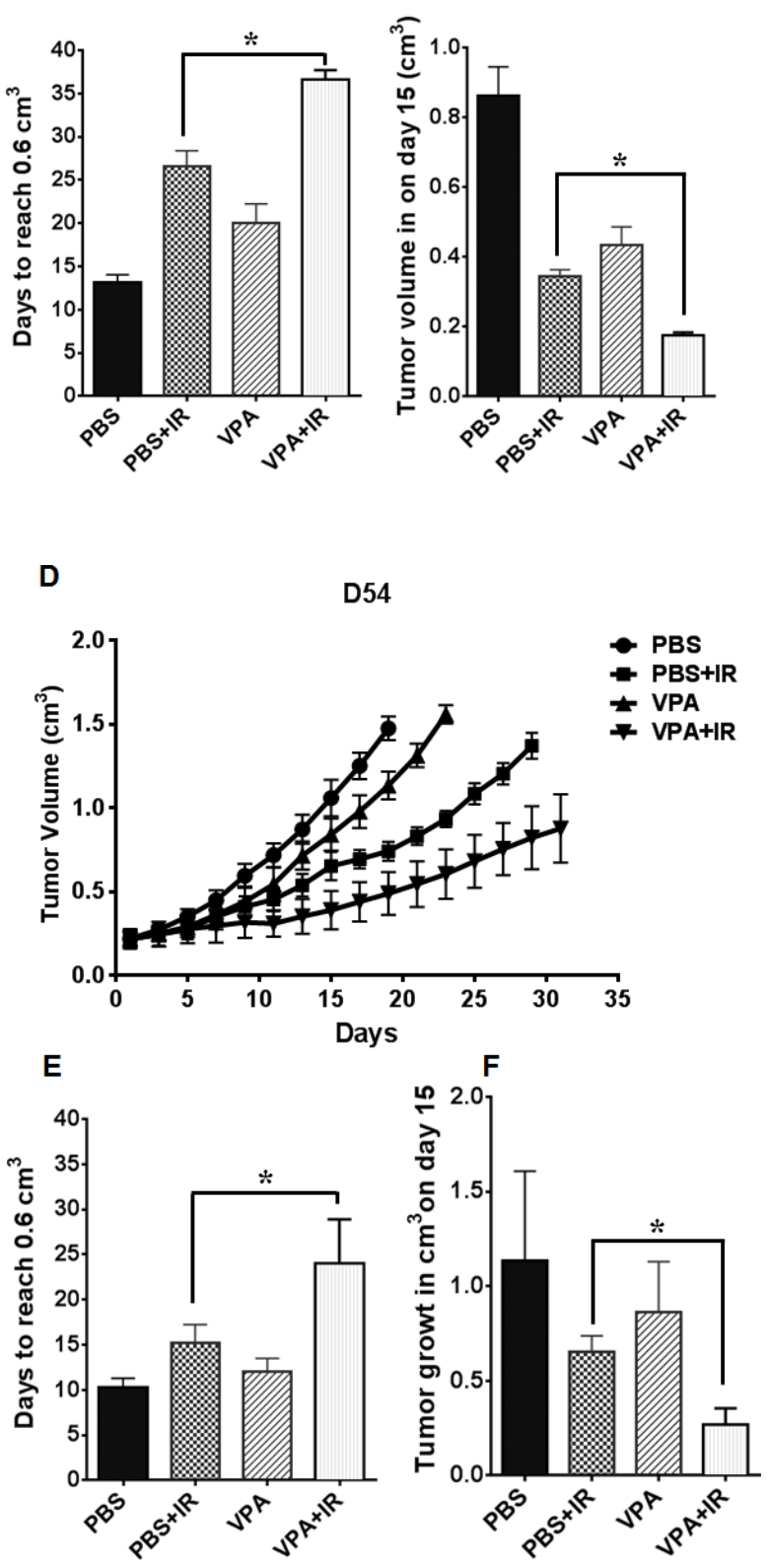

Figure 5: VPA delays tumor growth in irradiated mouse tumor models. GL261 or D54 cells were implanted into the right flank of nude mice. Once the tumors were palpable, they were irradiated with $2 \mathrm{~Gy}$ for 5 consecutive days for a total of $10 \mathrm{~Gy}$. Mice were treated with VPA $(300 \mathrm{mg} / \mathrm{Kg})$ or PBS $60 \mathrm{~min}$ prior to irradiation. Tumor volumes were measured using digital calipers. Shown are the mean tumor volumes with SD from each treatment group of eight mice $\mathbf{A} \& \mathbf{D}$, number of days to reach a tumor volume of $0.6 \mathrm{~cm}^{3} \mathbf{B} \& \mathbf{E}, * P<0.05$, mean tumor volume following various treatments on day $15 \mathbf{C ~ \& ~} \mathbf{F}, * P<0.05$. 
GL261 mouse tumor model that stably expressed luciferase. Tumor-bearing mice were screened using bioluminescence imaging (BLI) and stratified into 4 groups having similar distribution of tumor volumes. Nine mice in each group were then treated with PBS, irradiation alone (five daily fractions of $2 \mathrm{~Gy}$ ), VPA (300 mg/kg) alone for 5 days, or VPA (300 mg/kg) for 5 days followed by irradiation (five daily fractions of 2Gy). We obtained both contrast-enhanced $\mathrm{T}_{1}$-weighted and $\mathrm{T}_{2}$ weighted MR images for tumor growth analysis. We scanned the mice at three time points during these experiments: 1) prior to treatment (Baseline), 2) 7 days post treatment, and 3) 14 days post treatment (Fig. 6A). Regions of interest (ROI) were drawn manually around tumors using Image $\mathrm{J}$ software and the corresponding tumor volumes were calculated. The tumor volumes of all the treatment groups at the first baseline scan were similar, with no significant differences among the groups. In the second scan, seven days post treatment, tumor volumes for mice treated with either radiation $\left(13.9 \mathrm{~mm}^{3}\right)$ or VPA alone $\left(17.9 \mathrm{~mm}^{3}\right)$ were significantly smaller than PBS treated controls $\left(80.3 \mathrm{~mm}^{3}\right)$. The most significant reduction in volume was seen in mice treated with combination of VPA and radiation $\left(7.4 \mathrm{~mm}^{3}\right)$, indicating that such treatment reduced the growth of the glioblastoma tumor most efficiently (Fig. 6B). For the third scan (14 days post treatment), we scanned mice treated with VPA alone, irradiation alone and VPA in combination with irradiation. PBS treated control mice had to be euthanized due to tumor burden (Fig. 6A).
A

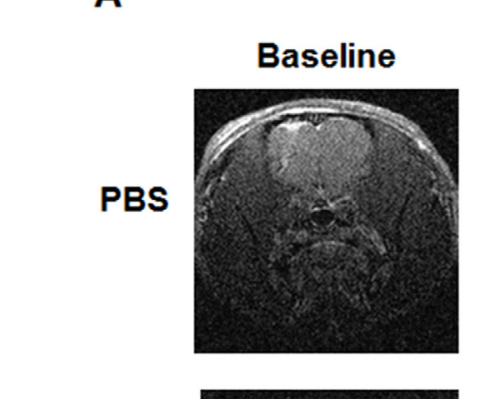

PBS + IR

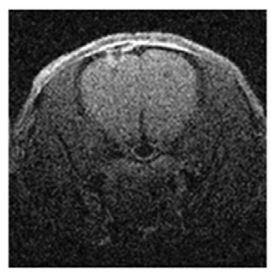

VPA
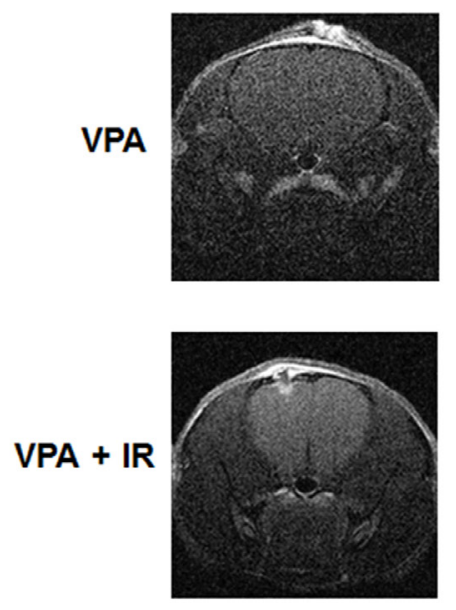

\section{7 days post baseline}
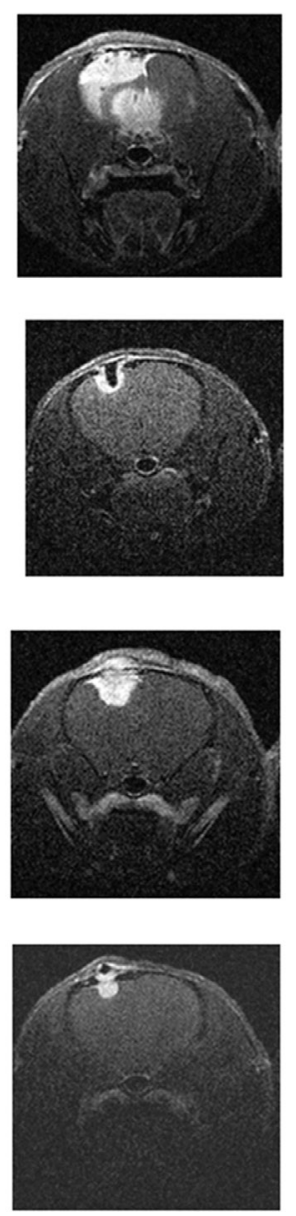

\section{4 days post baseline}
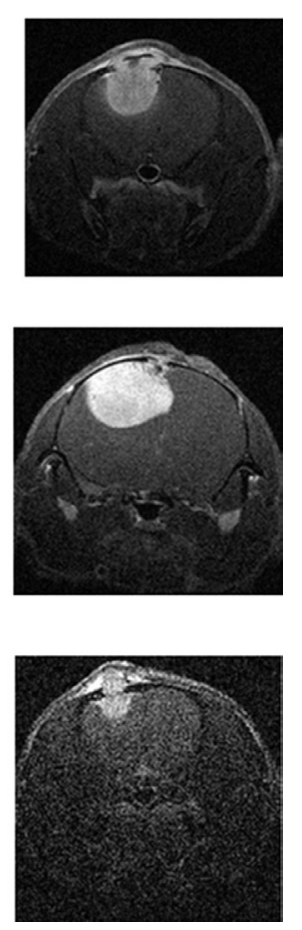

Figure 6: VPA in combination with irradiation improves survival by inhibiting tumor growth. Nude mice were implanted intracranially with GL261 cells stably expressing luciferase. After 10 days, mice were imaged with bioluminescence imaging and then serpentine sorted into four groups of nine each. Tumors were irradiated with $2 \mathrm{~Gy}$ or sham for five consecutive days shielding of the nonbrain areas of the body during irradiation. Mice were treated with VPA (300 mg/Kg) or PBS 60 min prior to irradiation. A. Representative, contrast-enhanced, T1-weighted images of mouse brain from each of the four groups (top to bottom: PBS, PBS + IR, VPA, VPA + IR) at baseline (left) and 7 days (middle) and 14 days (right) post treatment.

(Continued) 
B
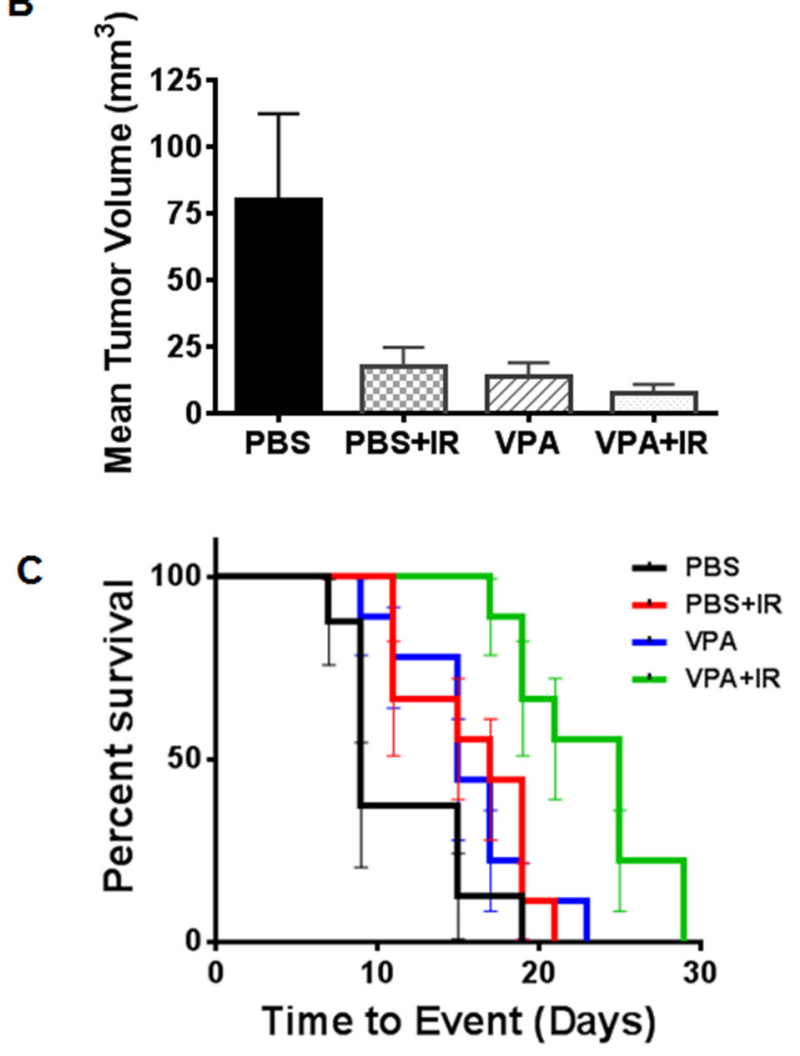

Figure 6: (Continued) B. Average, MRI-derived tumor volumes measured at seven days post-treatment. C. Kaplan-Meyer survival curves following various treatments of mice bearing intracranial tumors.

\section{VPA treatment in combination with irradiation improves survival by inhibiting tumor growth}

To determine the effects of VPA on the survival of orthotopic tumor bearing mice, we used an intracranial GL261 mouse glioblastoma model stably expressing luciferase. Tumor-bearing mice were screened using bioluminescence imaging, (BLI) and stratified into four groups of nine mice each having similar distribution of tumor volumes. The mice in each group were then treated with PBS alone, radiation alone (five daily fractions of $2 \mathrm{~Gy})$, VPA (300 mg/ $\mathrm{kg}$ ) alone for 5 days, or VPA $(300 \mathrm{mg} / \mathrm{kg}$ ) for 5 days followed by radiation (five daily fractions of $2 \mathrm{~Gy}$ ). We then analyzed the effect of the treatments on percent survival at the midpoint of the study (the $15^{\text {th }}$ day). Percent survival was $13 \%$ for PBS treated mice, $55 \%$ for mice treated with radiation and $44 \%$ for mice treated with VPA alone. In mice treated with VPA combined with radiation, 15-day survival was $100 \%$ (Fig. 6C). Using a Cox Proportional Hazard regression model we found that the mice receiving the combined treatment with VPA and radiation showed statistically significant increased survival when compared to PBS treated mice $(P=0.002)$, mice treated with radiation alone $(P=0.0130)$ or mice treated with VPA alone $(P=0.0140)$. The survival assay results indicate that treatment of mice with a combination of VPA and radiation was most effective (Fig. 6C).

\section{DISCUSSION}

Radiation therapy is an effective treatment for children with medulloblastoma and some forms of leukemia. Cranial irradiation, however, results in memory and learning deficits in children [71]. The age dependence of radiation-induced brain injury has led to delaying radiotherapy in infants [72]. Treatment of infants and children with low doses of radiation to the brain often leads to long lasting neurocognitive deficits that can become permanent $[73,74]$. These neurocognitive deficits manifest as declines in IQ and higher unemployment rates as compared to children treated with chemotherapy alone $[75,76]$. It has been proposed that the hippocampal neuron progenitor cells are the most affected, leading to the radiation-induced neurocognitive decline [77, 78]. Radiation-induced cognitive deficits involve apoptosis in the sub-granular region of the hippocampus and the subsequent diminished neurogenesis [78, 79]. The efficacy of radiotherapy can be improved by the use of radioprotectors that prevent radiation damage to normal 
tissues $[64,68,80,81]$. The efficacy of radiotherapy can also be improved by use of chemical agents that specifically sensitize cancer cells to radiation $[82,83]$.

In the present study, mouse hippocampus and hippocampus-derived cells (HT22) pretreated with VPA were protected from radiation damage. However, such radioprotection was not observed in the brain cancer cell lines (Daoy, D54 and GL261; Fig. 2B \& 2C), or in the GL261 and D54 tumor models (Fig. 5). The selective protection of hippocampal neurons could be due to modulations of radiation-induced pro-apoptotic signaling by VPA (Fig 1E). In contrast to hippocampal neurons in the sub-granular zone, cancer cells typically do not undergo apoptosis in response to ionizing radiation. Therapeutic radiation kills most tumor cells by post-mitotic cell death through mitotic catastrophe $[1,83]$. Hence this differential response to radiation provides a means to improve the therapeutic effect of cranial irradiation.

Following treatment of both normal hippocampal cells (HT22) and glioblastoma cells (GL261) with VPA, we found increased levels of acetylated histone H4, indicating that the activity of HDACs was inhibited in both normal and cancer cells (Fig 4). Several phenotypes associated with the effects of VPA are brought about by its action as an inhibitor of HDACs. These include its cytotoxicity and perturbation on the DNA damage repair machinery [22, 49]. Although VPA inhibits HDAC in both normal and cancer cells, it selectively kills cancer cells $[84,85]$. Several mechanisms have been proposed to explain the preferential selectivity killing of cancer cells by VPA and other HDAC inhibitors. None of the proposed mechanism so far can fully account for this generalized effect, found in multiple cell lines and tumor types irrespective of the different cell line specific control of gene transcription $[84,85]$. It has been shown that VPA induces a specific type of DNA damage that can be repaired in normal cells but not in cancer cells [86]. The nature of such DNA damage remains to be elucidated. There is evidence that HDAC inhibitors lower the cell's capacity to repair radiation-induced DNA damage. Such perturbations occur both at the level of DNA damage signaling and the major DNA repair pathways like NHEJ and HR $[85,87]$. VPA and other HDAC inhibitors have been shown to decrease several key players in the repair of DNA DSB in cancer cells, at the levels of protein and/ or mRNA as well as prolonged radiation-induced repair protein foci. These include $\mathrm{Ku} 70, \mathrm{Ku} 80$, DNA PK, ligase IV, XRCC4, RAD 51, RAD 50, ATM, $\gamma$-H2AX, BRCA1, BRCA2, and 53 BP1 [46, 87]. These alterations have been reported in cancer cells but not in normal cells. The participation of the acetylation of non-histone proteins in the increased radiosensitivity of HDAC treated cancer cells has been postulated, but remains to be demonstrated $[1,84,88]$

We found that VPA protected normal cells from radiation damage, which was in part due to the attenuation of radiation-induced apoptosis (Fig. 1A-1D; 2B). Such attenuation was associated with decreased levels of Bax, a proapoptotic protein and increased levels of Bcl-2, an antiapoptotic protein (Fig. 1E). Whether the attenuation of radiation-induced apoptosis in the hippocampus (Figs. 1A \& 1B) is also associated with alterations in the levels of these proteins remains to be determined.

We observed an increase in the phosphorylation of GSK3 $\beta$ (ser9) and stabilization of $\beta$-catenin, indicating the inhibition of the GSK3 $\beta$ activity by VPA treatment, but only in normal and not in cancer cells (Fig. 4). Previously we have shown that inhibition of GSK3 $\beta$ either with small molecule inhibitor or knockdown protected the hippocampal neurons from radiation-induced apoptosis and increased clonogenic survival [64, 89]. Further, we have shown that GSK $3 \beta$ inhibition enhances the repair of DNA DSB in irradiated normal hippocampal neurons (HT22) but not in glioma cells (GL261 and D54). This effect correlated with increased efficacy of end rejoining by the NHEJ DSB repair pathway [89]. Hence, we speculate that the neuroprotection of hippocampal neurons in vivo involves such enhancement of the efficacy of the NHEJ by GSK3 $\beta$. The lack of inhibition of VPAmediated GSK $3 \beta$ in glioma cells could be associated with the differential VPA sensitivity and radiation response of cancer cells.

VPA treatment has been reported to provide neuroprotection and improve cognitive function $[67,90]$. The neuroprotection and improved cognitive function was due, in part, to inhibition of HDAC and GSK3 $\beta$, which helped to stabilize antiapoptotic proteins like Bcl-2 in normal HT22 cells and prevent apoptosis ([67] Fig. 1C, 1D \& 1E). We also observed that VPA treatment reduced the levels of the pro apoptotic protein Bax (Fig. 1E).

VPA treatment induced a $\mathrm{G}_{2} / \mathrm{M}$ cell cycle arrest in GL261 cells (Fig 3). The accumulation of cells with $\mathrm{G}_{2} / \mathrm{M}$ DNA content is consistent with the induction of mitotic catastrophe as a mode of cell death in irradiated cells. Such effects have been reported for several glioma cells lines treated with VPA [91]. Taken all together, these results suggest that radioprotection by VPA is selective for hippocampal neurons, which could be mediated through the inhibition of HDAC and GSK3 $\beta$. Although there has been a report that VPA protected rat brains from radiation-induced damage, apoptosis in cerebral cortex cells and long-term blood vessel damage were not quantitated [92].

We used $300 \mathrm{mg} / \mathrm{kg}$ VPA in the studies demonstrating radioprotection of normal hippocampal neurons and radiosensitization of glioblastoma in mice. VPA administered at $300 \mathrm{mg} / \mathrm{Kg}$ in mice leads to a serum concentration between 265-280 $\mu \mathrm{g} / \mathrm{ml}$ [93]. At such serum concentrations, the maximum level of VPA in mouse brains is $17-30 \mu \mathrm{g} / \mathrm{g}[94,95]$. The half-life of VPA in mice is 1-3 hours [94], while in humans it is 9-18 hours $[96,97]$. In humans the maximum therapeutic dose 
for epilepsy and mania is $60 \mathrm{mg} / \mathrm{kg}$, which amounts to 750-4000 mg/day [96]. At these doses the therapeutic serum levels are $50-150 \mu \mathrm{g} / \mathrm{ml}$ of which the levels of free VPA are 6-32 $\mu \mathrm{g} / \mathrm{ml}[98,99]$. The levels of VPA in cerebrospinal fluid are usually similar to the free valproic acid levels $[100,101]$. There are differences in VPA metabolism between mice and humans. Thus the findings in mice are difficult to extrapolate directly to humans [102]. Nevertheless, we speculate that the levels of VPA in our studies are comparable to those associated with therapeutic ranges in humans [102].

We found that $300 \mathrm{mg} / \mathrm{kg}$ VPA significantly protected mouse hippocampal neurons from radiation damage by attenuating apoptosis (Fig. 1A). Similar neuroprotection by VPA has been observed in animals subjected to ischemia $[27,103]$, traumatic brain injury [67], and intracerebral hemorrhage [26]. HDAC and/ or GSK3 $\beta$ inhibition has been reported in various studies of animals treated with $300-400 \mathrm{mg} / \mathrm{kg}$ of VPA [67, 103, 104].

In preclinical studies treatment with VPA was reported to control the growth of a variety of tumors, including gliomas, neuroblastomas, medulloblastomas and melanomas $[22,49]$. VPA's antitumor effects involve the modulation of various cellular and tissue pathways, including cell-cycle arrest, angiogenesis, apoptosis, differentiation, senescence and DNA repair [22]. In the heterotopic GL261 and D54 tumor models, mice treated with VPA were half as likely to develop a tumor with a volume greater than $0.6 \mathrm{~cm}^{3}$ than PBS treated mice (Fig. $5 \mathrm{~B} \& 5 \mathrm{E})$. Tumor growth in mice treated with a combination of VPA and radiation was significantly delayed when compared to radiation alone, VPA alone or PBS treated controls (Fig. 5A \& 5B, 6A \& 6B). These results indicate that a combination of VPA with irradiation was significantly more effective in controlling tumor growth. VPA treatment alone was also effective in controlling tumor growth in mice and was significantly better than no treatment. More importantly, VPA treatment alone did not enhance tumor growth. These findings suggest that pre-treatment with VPA may significantly improve the response of malignant glioma to radiation therapy.

There are reports indicating that VPA alone or in combination therapy can increase the life span of both tumor bearing mice [105] and humans with brain cancer $[48,56,58,60,61]$. In clinical trials, valproic acid was the preferred antiepileptic agent in a combination therapy that utilized radiation and temozolomide [48]. Valproic acid has also been reported to enhance other combination therapies in treating intracranial gliomas in mice $[105,106]$. We found similar results while analyzing DCE MRI derived tumor volumes. Mice treated with a combination of VPA and radiation showed significantly reduced tumor growth compared to PBS treated mice (Fig. 6A \& 6B). Cox proportional hazards modeling was used to estimate the hazard ratio for overall survival between the treatment levels in the orthotopic intracranial tumor model. We found that mice with no treatment were 11.4 times $(p=0.0002)$ more likely to die than mice treated with combination of VPA and radiation. Mice treated with radiation alone were 4.7 times $(p=0.0130)$ more likely to die than mice treated with combination of VPA and radiation (Fig. 6C). The survival of mice correlated with the tumor volume as seen by DCE MRI (Figs 6A\&6B). Overall, these results indicate that VPA in combination with radiation can effectively control tumor growth in the brain, leading to improved survival.

VPA is now drawing attention due to its versatility in improving cognitive sequelae and protecting against various neurological insults, and is emerging as a promising drug for brain cancer treatment [56]. Our current findings on the radioprotective effects of VPA on the hippocampus and radio-sensitization effects of VPA in cancer cells also makes it attractive as a novel therapeutic strategy for the prevention of neurocognitive deficits resulting from cranial irradiation.

\section{MATERIALS AND METHODS}

\section{Chemicals, cell culture and treatments}

Valproic acid was purchased from Sigma. Mouse hippocampal neuronal cells HT22 were obtained from David Schubert (The Salk Institute; La Jolla, CA) and maintained in DMEM with 10\% fetal bovine serum (FBS) and $1 \%$ penicillin/streptomycin (Life Technologies). Human medulloblastoma Daoy cells were obtained from ATCC and propagated in Eagle's Minimum Essential Medium with 10\% FBS, 2 mM L-glutamine, $1.5 \mathrm{~g} / \mathrm{L}$ sodium bicarbonate, $0.1 \mathrm{mM}$ non-essential amino acids, and $1.0 \mathrm{mM}$ sodium pyruvate. Human glioma D54 and mouse glioma GL261 cell lines were obtained from Dr. Yancey Gillespie (University of Alabama-Birmingham, Birmingham, AL) and maintained in DMEM with Nutrient Mixture F-12 (1:1), 10\% FBS, 1\% sodium pyruvate and $1 \%$ penicillin/streptomycin (Life Technologies). All cells were grown in a $5 \% \mathrm{CO}_{2}$ incubator at $37^{\circ} \mathrm{C}$. Cells were irradiated at a dose rate of $2.5 \mathrm{~Gy} / \mathrm{min}$ using a RS2000 $160 \mathrm{kV}$ X-ray Irradiator with a $0.3 \mathrm{~mm}$ copper filter ( $\mathrm{Rad}$ Source Technologies).

\section{Histological staining for apoptosis using TUNEL}

One-week-old C57BL/6 mice pups were treated with daily i.p. injections of VPA $(300 \mathrm{mg} / \mathrm{kg})$ or PBS. On the seventh day of VPA treatment, the pups' brains were irradiated with 7 Gy. Twenty four hours later, the animals were sacrificed and their brains were harvested and fixed in $10 \%$ neutral buffered formalin. The fixed brains were embedded in paraffin and sectioned coronally. Five micron thick sections were placed on Superfrost Gold Plus slides, stained with the DeadEnd ${ }^{\mathrm{TM}}$ Colorimetric TUNEL System (Promega) according to the manufacturer's instructions, 
and counterstained with hematoxylin. For the TUNEL experiments, at least three animals were used in each experimental group. TUNEL positive cells (TPC) were counted using an Olympus BX51 microscope equipped with an Olympus DP26 digital camera. At least three high power fields (HPF) per animal were scored. The average number of TUNEL positive cells per HPF $(+/-\mathrm{SD})$ was calculated.

\section{Apoptosis assays for cultured cells}

Apoptosis was monitored by annexin V-APC/ propidium iodide staining using the Apoptosis Detection Kit according to the manufacturer's instructions (BD PharMingen). Briefly, HT22 cells were treated with PBS or VPA $(0.6 \mathrm{mM})$ for seven days, and then irradiated with 4 Gy. Sixteen hours post irradiations aliquots of $10^{5}$ cells were incubated with Annexin V/propidium iodide for 15 minutes at room temperature. The cells were then analyzed by flow cytometry, using a two-color MACS FCM analysis system (Miltenyi Biotech). For each treatment, the average fold-increase of apoptotic cells over control (+/- SD) was calculated.

In separate experiments, the apoptotic nuclei of HT22 cells were counted after staining with 4', 6-diamidino-2-phenylindole (DAPI). The treated cells were washed with PBS, fixed in $70 \%$ ethanol at room temperature for 10 minutes, and stained with DAPI (Vector Labs). The nuclear morphology was monitored using an Olympus BX60 fluorescence microscope equipped with a Retiga 2000R digital camera. Apoptosis was quantified by scoring the percentage of cells with apoptotic nuclear morphology at the single cell level. Condensed or fragmented nuclei were scored as apoptotic; the average percentage of apoptotic cells (+/- SD) was calculated in 5-7 randomly selected HPF.

\section{Colony formation assay}

Equal numbers of GL261 and HT22 cells were plated on $60 \mathrm{~mm}$ dishes. After 4-5 h, cells were treated with either PBS or $0.6 \mathrm{mM}$ VPA for seven days. Colonies were allowed to form for 10 days, after which cells were fixed with $70 \%$ ethanol and stained with $1 \%$ methylene blue. Colonies having greater than 50 cells were counted under a microscope and the results plotted. Experiments were repeated in triplicate and standard errors were calculated.

\section{Clonogenic survival assay}

Defined numbers of cells were plated and allowed to attach for 5 hours and then irradiated with $0,2,4,6$ or 8 Gy. After 7-10-day incubation, plates were fixed with $70 \%$ ethanol and stained with $1 \%$ methylene blue. Colonies consisting of more than 50 cells were counted by viewing the plates under a StemiVD4 dissecting microscope (Zeiss). The survival fractions were calculated as (number of colonies/number of cells plated)/(number of colonies for corresponding control/number of control cells plated). The dose modifying factors at $10 \%$ survival $\left(\mathrm{DMF}_{10}\right)$ were calculated from the survival curves by taking the ratio of the dose of IR that reduced survival to $10 \%$ divided by the dose of IR that reduced survival to $10 \%$ in the presence VPA.

\section{Immunoblotting}

Total protein was extracted from treated cells using the M-PER mammalian protein extraction reagent (Pierce). Protein concentration was determined using the BCA Reagent (Pierce). Protein extracts were analyzed using antibodies for the detection of phospho-GSK3 $\beta^{\text {Ser-9 }}$, GSK3 $\beta$, $\beta$-catenin, PARP, Bcl-2 (Cell Signaling Technologies), Acetyl H4 (Millipore) and Bax (Santa Cruz). Antibody against actin (Sigma) was used to normalize protein loading in each lane. Bands were visualized using the Western Lightning Chemiluminescence Plus detection system (PerkinElmer), according to the manufacturer's protocol.

\section{Colorimetric cell proliferation assay}

Cell proliferation was determined using Cell Titer 96 aqueous non-radioactive cell proliferation assay reagent (Promega). The assay was performed following the manufacturer's protocol. Briefly, cells were treated with PBS or $0.6 \mathrm{mM}$ VPA for seven days and equal numbers of treated HT22 (1000 cells), GL261 (2000 cells), D54 (2000 cells) and Daoy (2000 cells) cells were plated in 96-well plates. The cells plated in the 96 well plates had the respective drug or vehicle control. Cell viability was determined after incubation for $96 \mathrm{~h}$ by measuring the absorbance at $490 \mathrm{~nm}$ with a Countess II L plate reader (Life Technologies). The cells in 96-well plate were visually scanned in an inverted microscope AE30 (Motic) after $96 \mathrm{~h}$ of incubation, to ensure that cells were not overly confluent in some experimental arms before performing the proliferation assay. Experiments were performed in triplicate, and both average fold changes relative to controls and standard errors were calculated.

\section{Cell cycle analysis by flow cytometry}

HT22 and GL261 cells were treated with PBS or $0.6 \mathrm{mM}$ VPA for seven days, and then irradiated with 4Gy. Twenty-four hours post irradiation; treated cells were washed with PBS, fixed in 70\% ethanol, and incubated overnight at $-20^{\circ} \mathrm{C}$. Cells were pelleted and resuspended in PBS with DNAse-free RNAse $(20 \mu \mathrm{g} / \mathrm{ml})$ and incubated at $37^{\circ} \mathrm{C}$ for $30 \mathrm{~min}$. The cells were then stained with propidium iodide $(50 \mu \mathrm{g} / \mathrm{ml})$ at room temperature for $15 \mathrm{~min}$ and analyzed by flow cytometry. Cell cycle 
analysis was performed using Modfit LT 3.0 software. The average fractions of cells in the $\mathrm{G}_{1}, \mathrm{G}_{0}, \mathrm{G}_{2}-\mathrm{M}$ and $\mathrm{S}$ phases of the cell cycle were determined and the standard error was calculated from three separate experiments.

\section{Mice and treatments}

$\mathrm{C} 57 \mathrm{BL} / 6$ and $\mathrm{Nu} / \mathrm{Nu}$ mice (Harlan) were used for animal studies. Animal procedures were approved by the Institutional Animal Care and Use Committee (IACUC) at Washington University School of Medicine in St. Louis. Mice were irradiated at a dose rate of $1 \mathrm{~Gy} / \mathrm{min}$ using RS2000 $160 \mathrm{kV}$ X-ray Irradiator with a $0.3 \mathrm{~mm}$ copper filter ( $\mathrm{Rad}$ Source Technologies). Mice were anesthetized with $2.5 \%$ isoflurane delivered using oxygen to immobilize the mice. Only the intended organ or the tumor was exposed and the rest was shielded with lead during irradiation.

\section{Tumor growth delay}

One million GL261 or D54 cells were injected into the right flank of each C57BL/6 mouse. Once tumors were palpable, mice were stratified into four treatment groups of eight each representing similar distributions of tumor sizes. Tumors from two groups of mice were irradiated with 2 Gy fractions daily for five consecutive days for a total of $10 \mathrm{~Gy}$. These mice received either $300 \mathrm{mg} / \mathrm{kg}$ VPA or PBS as vehicle control by intraperitoneal injection (i.p.), $60 \mathrm{~min}$ prior to each irradiation. Two groups of nonirradiated mice received either $300 \mathrm{mg} / \mathrm{kg}$ VPA or PBS alone by i.p. injection daily for five days as well. Tumor volumes in the mouse hind limbs were measured using calipers. The mean tumor volume and standard error were calculated for each treatment group.

\section{Intracranial tumors}

Orthotopic intracranial tumors were induced by stereotactically injecting $5 \times 10^{4}$ GL261-FG cells into the brains of six-week-old nude mice at a position $2 \mathrm{~mm}$ lateral to the bregma at a depth of $3 \mathrm{~mm}$. The GL261FG cells were transduced with a lentivirus for stable expression of both firefly luciferase and green fluorescent protein. Ten days after injecting the GL261-FG cells, the presence of tumor was confirmed by bioluminescence imaging (BLI) [107]. The mice were then stratified into four treatment groups of nine, each representing similar distributions of tumor sizes. Tumors from two groups of mice were irradiated daily with 2 Gy for five consecutive days for a total of 10 Gy. Mice were anesthetized and irradiated in a holder designed to irradiate the tumor region in the head only and shield the rest of the body with lead during irradiation. These mice received either $300 \mathrm{mg} / \mathrm{kg}$ VPA or PBS as vehicle control i.p., $60 \mathrm{~min}$ prior to irradiation. Two groups of non-irradiated mice also received either $300 \mathrm{mg} / \mathrm{kg}$ VPA or PBS alone i.p., daily for five days as well. Over the course of 30 days, mice were weighed daily and monitored closely for the signs of pre-morbid state. These signs included hypoactivity, shallow, rapid and/or labored breathing, failure to groom, failure to respond to stimuli, hunched posture, dehydration and weight loss. When any of these signs were present, mice were euthanized. Surviving animals were euthanized at the end of the experiment (45 days after tumor implantation). Survival was calculated using Kaplan-Meyer analysis.

\section{MRI imaging of intracranial tumors}

Magnetic resonance images were collected using an Oxford Instruments 4.7-T magnet (40 cm, clear bore) equipped with 21-cm inner diameter, actively shielded Agilent/Magnex (Yarnton) gradient coils (maximum gradient $28 \mathrm{G} / \mathrm{cm}$; rise time $\sim 650 \mu \mathrm{s}$ ) driven by model A-240 amplifiers (Oy International Electric Company) The magnet/gradients were interfaced with an Agilent/ Varian Direct Drive console, and data were collected using a 1.5-cm OD surface coil (receive) and a 5-cm ID Helmholtz coil (transmit) actively decoupled coil pair as described [108]. Before the imaging experiments, mice were anesthetized with isoflurane $/ \mathrm{O}_{2}[2-3 \%(\mathrm{v} / \mathrm{v})]$, and maintained on isoflurane $/ \mathrm{O}_{2}[1 \%(\mathrm{v} / \mathrm{v})]$ throughout the experiments. Animal body temperature was maintained at $37^{\circ} \mathrm{C}$ using a pad heated with warm circulating water. Mice were injected i.p. with $500 \mu$ l MultiHance contrast agent (Bracco Imaging), diluted 1:10 in sterile saline, 15 minutes prior to being placed in the magnet. $\mathrm{T}_{1}$-weighted, spin-echo multi-slice transaxial images were collected with $\mathrm{T}_{\mathrm{R}}=0.65 \mathrm{~s}, \mathrm{~T}_{\mathrm{E}}=0.02 \mathrm{~s}, \mathrm{FOV}=1.5 \times$ $1.5 \mathrm{~cm}^{2}$, slice thickness $=0.5 \mathrm{~mm}$.

\section{Statistical analyses}

The means and standard deviations (SD) of each treatment group were calculated for all experiments. The number of samples is indicated in the description of each experiment. Kaplan-Meier and Cox Proportional Hazards models were used to analyze survival data, while non-parametric Kruskal-Wallis analysis was used to compare treatment effectiveness on tumor growth delay. All pair-wise comparisons between treatment groups were adjusted using Tukey's multiple comparison method. A $p$-value of $<0.05$ was considered statistically significant.

\section{ACKNOWLEDGMENTS}

This work was supported by National Cancer Institute grants 1R01CA140220-02, 5R01CA125757-06, 7R01CA112385-0, Siteman Cancer Research Award, 
Elizabeth and James McDonnell III Endowment (D. Hallahan), Department of Radiation Oncology Startup Funds (D. Thotala), The Alvin J. Siteman Cancer Center at Washington University, an NCI Comprehensive Cancer Center P30 CA91842 (J. Garbow).

\section{CONFLICTS OF INTEREST}

All authors declare no conflicts of interest.

\section{REFERENCES}

1. Liauw SL, Connell PP, Weichselbaum RR. New paradigms and future challenges in radiation oncology: an update of biological targets and technology. Science translational medicine. 2013; 5:173-172.

2. Morris ZS, Harari PM. Interaction of radiation therapy with molecular targeted agents. J Clin Oncol. 2014; 32:2886-2893.

3. Meadows AT, Gordon J, Massari DJ, Littman P, Fergusson J, Moss K. Declines in IQ scores and cognitive dysfunctions in children with acute lymphocytic leukaemia treated with cranial irradiation. Lancet. 1981; 2:1015-1018.

4. Jannoun L, Bloom HJ. Long-term psychological effects in children treated for intracranial tumors. Int J Radiat Oncol Biol Phys. 1990; 18:747-753.

5. Welzel G, Fleckenstein K, Mai SK, Hermann B, KrausTiefenbacher U, Wenz F. Acute neurocognitive impairment during cranial radiation therapy in patients with intracranial tumors. Strahlenther Onkol. 2008; 184:647-654.

6. Schmidt-Hieber C, Jonas P, Bischofberger J. Enhanced synaptic plasticity in newly generated granule cells of the adult hippocampus. Nature. 2004; 429:184-187.

7. van Praag H, Schinder AF, Christie BR, Toni N, Palmer TD, Gage FH. Functional neurogenesis in the adult hippocampus. Nature. 2002; 415:1030-1034.

8. Kempermann G, Wiskott L, Gage FH. Functional significance of adult neurogenesis. Curr Opin Neurobiol. 2004; 14:186-191.

9. Squire LR, Stark CE, Clark RE. The medial temporal lobe. Annu Rev Neurosci. 2004; 27:279-306.

10. Deweer B, Pillon B, Pochon JB, Dubois B. Is the HM story only a "remote memory"? Some facts about hippocampus and memory in humans. Behav Brain Res. 2001; 127:209-224.

11. Peissner W, Kocher M, Treuer H, Gillardon F. Ionizing radiation-induced apoptosis of proliferating stem cells in the dentate gyrus of the adult rat hippocampus. Brain Res Mol Brain Res. 1999; 71:61-68.

12. Mizumatsu S, Monje ML, Morhardt DR, Rola R, Palme TD, Fike JR. Extreme sensitivity of adult neurogenesis to low doses of X-irradiation. Cancer Res. 2003; 63:4021-4027.
13. Monje ML, Mizumatsu S, Fike JR, Palmer TD. Irradiation induces neural precursor-cell dysfunction. Nature medicine. 2002; 8:955-962.

14. Tada E, Parent JM, Lowenstein DH, Fike JR. X-irradiation causes a prolonged reduction in cell proliferation in the dentate gyrus of adult rats. Neuroscience. 2000; 99:33-41.

15. Madsen TM, Kristjansen PE, Bolwig TG, Wortwein G. Arrested neuronal proliferation and impaired hippocampal function following fractionated brain irradiation in the adult rat. Neuroscience. 2003; 119:635-642.

16. Abayomi OK. Pathogenesis of cognitive decline following therapeutic irradiation for head and neck tumors. Acta oncologica (Stockholm, Sweden). 2002; 41:346-351.

17. Abayomi OK. Pathogenesis of irradiation-induced cognitive dysfunction. Acta oncologica (Stockholm, Sweden). 1996; 35:659-663.

18. Roman DD, Sperduto PW. Neuropsychological effects of cranial radiation: current knowledge and future directions. International Journal of Radiation Oncology*Biology*Physics. 1995; 31:983-998.

19. Nagai R, Tsunoda S, Hori Y, Asada H. Selective vulnerability to radiation in the hippocampal dentate granule cells. Surg Neurol. 2000; 53:503-506. discussion 506-507.

20. Brown PD, Pugh S, Laack NN, Wefel JS, Khuntia D, Meyers C, Choucair A, Fox S, Suh JH, Roberge D, Kavadi V, Bentzen SM, Mehta MP, Watkins-Bruner D, Radiation Therapy Oncology G. Memantine for the prevention of cognitive dysfunction in patients receiving whole-brain radiotherapy: a randomized, double-blind, placebo-controlled trial. Neuro-oncology. 2013; 15:1429-1437.

21. Zhang L, Li K, Sun R, Zhang Y, Ji J, Huang P, Yang H, Tian Y. Minocycline ameliorates cognitive impairment induced by whole-brain irradiation: an animal study. Radiation oncology. 2014; 9:281.

22. Chateauvieux S, Morceau F, Dicato M, Diederich M. Molecular and therapeutic potential and toxicity of valproic acid. Journal of biomedicine \& biotechnology. 2010; 2010.

23. Eleuteri S, Monti B, Brignani S, Contestabile A. Chronic dietary administration of valproic acid protects neurons of the rat nucleus basalis magnocellularis from ibotenic acid neurotoxicity. Neurotox Res. 2009; 15:127-132.

24. Leng Y, Chuang DM. Endogenous alpha-synuclein is induced by valproic acid through histone deacetylase inhibition and participates in neuroprotection against glutamate-induced excitotoxicity. J Neurosci. 2006; 26:7502-7512.

25. Leng $\mathrm{Y}$, Liang $\mathrm{MH}$, Ren $\mathrm{M}$, Marinova Z, Leeds $\mathrm{P}$, Chuang DM. Synergistic neuroprotective effects of lithium and valproic acid or other histone deacetylase inhibitors in neurons: roles of glycogen synthase kinase-3 inhibition. J Neurosci. 2008; 28:2576-2588.

26. Sinn DI, Kim SJ, Chu K, Jung KH, Lee ST, Song EC, Kim JM, Park DK, Kun Lee S, Kim M, Roh JK. Valproic acid-mediated neuroprotection in intracerebral hemorrhage 
via histone deacetylase inhibition and transcriptional activation. Neurobiol Dis. 2007; 26:464-472.

27. Kim HJ, Rowe M, Ren M, Hong JS, Chen PS, Chuang DM. Histone deacetylase inhibitors exhibit anti-inflammatory and neuroprotective effects in a rat permanent ischemic model of stroke: multiple mechanisms of action. J Pharmacol Exp Ther. 2007; 321:892-901.

28. Costa C, Martella G, Picconi B, Prosperetti C, Pisani A, Di Filippo M, Pisani F, Bernardi G, Calabresi P. Multiple mechanisms underlying the neuroprotective effects of antiepileptic drugs against in vitro ischemia. Stroke. 2006; 37:1319-1326.

29. Morland C, Boldingh KA, Iversen EG, Hassel B. Valproate is neuroprotective against malonate toxicity in rat striatum: an association with augmentation of high-affinity glutamate uptake. J Cereb Blood Flow Metab. 2004; 24:1226-1234.

30. Wang JF, Azzam JE, Young LT. Valproate inhibits oxidative damage to lipid and protein in primary cultured rat cerebrocortical cells. Neuroscience. 2003; 116:485-489.

31. Harikrishnan KN, Karagiannis TC, Chow MZ, El-Osta A. Effect of valproic acid on radiation-induced DNA damage in euchromatic and heterochromatic compartments. Cell Cycle. 2008; 7:468-476.

32. Eyal S, Yagen B, Sobol E, Altschuler Y, Shmuel M, Bialer M. The activity of antiepileptic drugs as histone deacetylase inhibitors. Epilepsia. 2004; 45:737-744.

33. Jeong MR, Hashimoto R, Senatorov VV, Fujimaki K, Ren M, Lee MS, Chuang DM. Valproic acid, a mood stabilizer and anticonvulsant, protects rat cerebral cortical neurons from spontaneous cell death: a role of histone deacetylase inhibition. FEBS Lett. 2003; 542:74-78.

34. Marinova Z, Ren M, Wendland JR, Leng Y, Liang MH, Yasuda S, Leeds P, Chuang DM. Valproic acid induces functional heat-shock protein 70 via Class I histone deacetylase inhibition in cortical neurons: a potential role of Sp1 acetylation. J Neurochem. 2009; 111:976-987.

35. Gottlicher M, Minucci S, Zhu P, Kramer OH, Schimpf A, Giavara S, Sleeman JP, Lo Coco F, Nervi C, Pelicci PG, Heinzel T. Valproic acid defines a novel class of HDAC inhibitors inducing differentiation of transformed cells. The EMBO journal. 2001; 20:6969-6978.

36. Kramer $\mathrm{OH}$, Zhu P, Ostendorff HP, Golebiewski M, Tiefenbach J, Peters MA, Brill B, Groner B, Bach I, Heinzel T, Gottlicher M. The histone deacetylase inhibitor valproic acid selectively induces proteasomal degradation of HDAC2. The EMBO journal. 2003; 22:3411-3420.

37. Blaheta RA, Michaelis M, Driever PH, Cinatl J Jr. Evolving anticancer drug valproic acid: insights into the mechanism and clinical studies. Medicinal research reviews. 2005; 25:383-397.

38. Phiel CJ, Zhang F, Huang EY, Guenther MG, Lazar MA, Klein PS. Histone deacetylase is a direct target of valproic acid, a potent anticonvulsant, mood stabilizer, and teratogen. J Biol Chem. 2001; 276:36734-36741.
39. Shabason JE, Tofilon PJ, Camphausen K. Grand rounds at the National Institutes of Health: HDAC inhibitors as radiation modifiers, from bench to clinic. J Cell Mol Med. 2011; 15:2735-2744.

40. Hall AC, Brennan A, Goold RG, Cleverley K, Lucas FR, Gordon-Weeks PR, Salinas PC. Valproate regulates GSK-3-mediated axonal remodeling and synapsin I clustering in developing neurons. Mol Cell Neurosci. 2002; 20:257-270.

41. Chen PS, Peng GS, Li G, Yang S, Wu X, Wang CC, Wilson B, Lu RB, Gean PW, Chuang DM, Hong JS. Valproate protects dopaminergic neurons in midbrain neuron/ glia cultures by stimulating the release of neurotrophic factors from astrocytes. Mol Psychiatry. 2006; 11:1116-1125.

42. Butt MU, Sailhamer EA, Li Y, Liu B, Shuja F, Velmahos GC, DeMoya M, King DR, Alam HB. Pharmacologic resuscitation: cell protective mechanisms of histone deacetylase inhibition in lethal hemorrhagic shock. J Surg Res. 2009; 156:290-296.

43. Karagiannis TC, $\mathrm{Kn} \mathrm{H}$, El-Osta A. The epigenetic modifier, valproic acid, enhances radiation sensitivity. Epigenetics. 2006; 1:131-137.

44. Yeow WS, Ziauddin MF, Maxhimer JB, Shamimi-Noori S, Baras A, Chua A, Schrump DS, Nguyen DM. Potentiation of the anticancer effect of valproic acid, an antiepileptic agent with histone deacetylase inhibitory activity, by the kinase inhibitor Staurosporine or its clinically relevant analogue UCN-01. Br J Cancer. 2006; 94:1436-1445.

45. Camphausen K, Cerna D, Scott T, Sproull M, Burgan WE, Cerra MA, Fine H, Tofilon PJ. Enhancement of in vitro and in vivo tumor cell radiosensitivity by valproic acid. Int J Cancer. 2005; 114:380-386.

46. Chen X, Wong P, Radany E, Wong JY. HDAC inhibitor, valproic acid, induces p53-dependent radiosensitization of colon cancer cells. Cancer biotherapy \& radiopharmaceuticals. 2009; 24:689-699.

47. Gavrilov V, Leibovich Y, Ariad S, Lavrenkov K, Shany S. A combined pretreatment of 1,25-dihydroxyvitamin D3 and sodium valproate enhances the damaging effect of ionizing radiation on prostate cancer cells. J Steroid Biochem Mol Biol. 2010; 121:391-394.

48. Weller M, Gorlia T, Cairncross JG, van den Bent MJ, Mason W, Belanger K, Brandes AA, Bogdahn U, Macdonald DR, Forsyth P, Rossetti AO, Lacombe D, Mirimanoff RO, Vecht CJ, Stupp R. Prolonged survival with valproic acid use in the EORTC/NCIC temozolomide trial for glioblastoma. Neurology. 2011; 77:1156-1164.

49. Duenas-Gonzalez A, Candelaria M, Perez-Plascencia C, Perez-Cardenas E, de la Cruz-Hernandez E, Herrera LA. Valproic acid as epigenetic cancer drug: preclinical, clinical and transcriptional effects on solid tumors. Cancer Treat Rev. 2008; 34:206-222.

50. Bedford JS, Dewey WC. Radiation Research Society. 1952-2002. Historical and current highlights in radiation 
biology: has anything important been learned by irradiating cells? Radiat Res. 2002; 158:251-291.

51. Oleinick NL, Balasubramaniam U, Xue L, Chiu S. Nuclear structure and the microdistribution of radiation damage in DNA. Int J Radiat Biol. 1994; 66:523-529.

52. Oleinick NL, Chiu SM, Friedman LR. Gamma radiation as a probe of chromatin structure: damage to and repair of active chromatin in the metaphase chromosome. Radiat Res. 1984; 98:629-641.

53. Florenes VA, Skrede M, Jorgensen K, Nesland JM. Deacetylase inhibition in malignant melanomas: impact on cell cycle regulation and survival. Melanoma Res. 2004; 14:173-181.

54. Bacon CL, Gallagher HC, Haughey JC, Regan CM. Antiproliferative action of valproate is associated with aberrant expression and nuclear translocation of cyclin D3 during the C6 glioma G1 phase. J Neurochem. 2002; 83:12-19.

55. Catalano MG, Fortunati N, Pugliese M, Costantino L, Poli R, Bosco O, Boccuzzi G. Valproic acid induces apoptosis and cell cycle arrest in poorly differentiated thyroid cancer cells. J Clin Endocrinol Metab. 2005; 90:1383-1389.

56. Yuan Y, Xiang W, Qing M, Yanhui L, Jiewen L, Yunhe M. Survival analysis for valproic acid use in adult glioblastoma multiforme: a meta-analysis of individual patient data and a systematic review. Seizure. 2014; 23:830-835.

57. Oberndorfer S, Piribauer M, Marosi C, Lahrmann H, Hitzenberger P, Grisold W. P450 enzyme inducing and non-enzyme inducing antiepileptics in glioblastoma patients treated with standard chemotherapy. Journal of neurooncology. 2005; 72:255-260.

58. Kerkhof M, Dielemans JC, van Breemen MS, Zwinkels H, Walchenbach R, Taphoorn MJ, Vecht CJ. Effect of valproic acid on seizure control and on survival in patients with glioblastoma multiforme. Neuro-oncology. 2013; 15:961-967.

59. Guthrie GD, Eljamel S. Impact of particular antiepileptic drugs on the survival of patients with glioblastoma multiforme. Journal of neurosurgery. 2013; 118:859-865.

60. Barker CA, Bishop AJ, Chang M, Beal K, Chan TA. Valproic acid use during radiation therapy for glioblastoma associated with improved survival. Int J Radiat Oncol Biol Phys. 2013; 86:504-509.

61. Felix FH, de Araujo OL, da Trindade KM, Trompieri NM, Fontenele JB. Survival of children with malignant brain tumors receiving valproate: a retrospective study. Child's nervous system : ChNS : official journal of the International Society for Pediatric Neurosurgery. 2013; 29:195-197.

62. Vecht CJ, Kerkhof M, Duran-Pena A. Seizure prognosis in brain tumors: new insights and evidence-based management. The oncologist. 2014; 19:751-759.

63. Stupp R, Mason WP, van den Bent MJ, Weller M, Fisher B, Taphoorn MJ, Belanger K, Brandes AA, Marosi C, Bogdahn U, Curschmann J, Janzer RC, Ludwin SK, Gorlia T, Allgeier A, Lacombe D, et al. Radiotherapy plus concomitant and adjuvant temozolomide for glioblastoma. N Engl J Med. 2005; 352:987-996.

64. Thotala DK, Hallahan DE, Yazlovitskaya EM. Inhibition of glycogen synthase kinase 3 beta attenuates neurocognitive dysfunction resulting from cranial irradiation. Cancer Res. 2008; 68:5859-5868.

65. Johnson $\mathrm{MD}$, Xiang $\mathrm{H}$, London $\mathrm{S}$, Kinoshita $\mathrm{Y}$, Knudson M, Mayberg M, Korsmeyer SJ, Morrison RS. Evidence for involvement of Bax and p53, but not caspases, in radiation-induced cell death of cultured postnatal hippocampal neurons. J Neurosci Res. 1998; 54:721-733.

66. Chen G, Huang LD, Jiang YM, Manji HK. The moodstabilizing agent valproate inhibits the activity of glycogen synthase kinase-3. J Neurochem. 1999; 72:1327-1330.

67. Dash PK, Orsi SA, Zhang M, Grill RJ, Pati S, Zhao J, Moore AN. Valproate administered after traumatic brain injury provides neuroprotection and improves cognitive function in rats. PloS one. 2010; 5:e11383.

68. Thotala DK, Geng L, Dickey AK, Hallahan DE, Yazlovitskaya EM. A new class of molecular targeted radioprotectors: GSK-3beta inhibitors. Int J Radiat Oncol Biol Phys. 2010; 76:557-565.

69. Thotala DK, Hallahan DE, Yazlovitskaya EM. Glycogen synthase kinase 3 beta inhibitors protect hippocampal neurons from radiation-induced apoptosis by regulating MDM2-p53 pathway. Cell death and differentiation. 2012; 19:387-396.

70. Chie EK, Shin JH, Kim JH, Kim HJ, Kim IA, Kim IH. In Vitro and In Vivo Radiosensitizing Effect of Valproic Acid on Fractionated Irradiation. Cancer research and treatment : official journal of Korean Cancer Association. 2015; 47:527-533.

71. Spiegler BJ, Bouffet E, Greenberg ML, Rutka JT, Mabbott DJ. Change in neurocognitive functioning after treatment with cranial radiation in childhood. J Clin Oncol. 2004; 22:706-713.

72. Palmer SL, Goloubeva O, Reddick WE, Glass JO, Gajjar A, Kun L, Merchant TE, Mulhern RK. Patterns of intellectual development among survivors of pediatric medulloblastoma: a longitudinal analysis. J Clin Oncol. 2001; 19:2302-2308.

73. Radcliffe J, Bunin GR, Sutton LN, Goldwein JW, Phillips PC. Cognitive deficits in long-term survivors of childhood medulloblastoma and other noncortical tumors: age-dependent effects of whole brain radiation. Int J Dev Neurosci. 1994; 12:327-334.

74. Duffner PK. Long-term effects of radiation therapy on cognitive and endocrine function in children with leukemia and brain tumors. Neurologist. 2004; 10:293-310.

75. Anderson VA, Godber T, Smibert E, Weiskop S, Ekert H. Cognitive and academic outcome following cranial irradiation and chemotherapy in children: a longitudinal study. British journal of cancer. 2000; 82:255-262. 
76. Pui $\mathrm{CH}$, Cheng $\mathrm{C}$, Leung $\mathrm{W}$, Rai SN, Rivera GK, Sandlund JT, Ribeiro RC, Relling MV, Kun LE, Evan WE, Hudson MM. Extended follow-up of long-term survivors of childhood acute lymphoblastic leukemia. N Engl J Med. 2003; 349:640-649.

77. Acharya MM, Lan ML, Kan VH, Patel NH, Giedzinski E, Tseng BP, Limoli CL. Consequences of ionizing radiationinduced damage in human neural stem cells. Free radical biology \& medicine. 2010; 49:1846-1855.

78. Parihar VK, Limoli CL. Cranial irradiation compromises neuronal architecture in the hippocampus. Proceedings of the National Academy of Sciences of the United States of America. 2013; 110:12822-12827.

79. Fike JR, Rosi S, Limoli CL. Neural precursor cells and central nervous system radiation sensitivity. Semin Radiat Oncol. 2009; 19:122-132.

80. Thotala D, Chetyrkin S, Hudson B, Hallahan D, Voziyan P, Yazlovitskaya E. Pyridoxamine protects intestinal epithelium from ionizing radiation-induced apoptosis. Free radical biology \& medicine. 2009; 47:779-785.

81. Yazlovitskaya EM, Edwards E, Thotala D, Fu A, OsuskyxKL, Whetsell WO Jr., Boone B, Shinohara ET, Hallahan DE. Lithium treatment prevents neurocognitive deficit resulting from cranial irradiation. Cancer Res. 2006; 66:11179-11186.

82. Kinsella TJ, Vielhuber KA, Kunugi KA, Schupp J, Davis TW, Sands H. Preclinical toxicity and efficacy study of a 14-day schedule of oral 5-iodo-2-pyrimidinone2'-deoxyribose as a prodrug for 5-iodo-2'-deoxyuridine radiosensitization in U251 human glioblastoma xenografts. Clin Cancer Res. 2000; 6:1468-1475.

83. Moding EJ, Kastan MB, Kirsch DG. Strategies for optimizing the response of cancer and normal tissues to radiation. Nature reviews Drug discovery. 2013; 12:526-542.

84. Carrier F. Chromatin Modulation by Histone Deacetylase Inhibitors: Impact on Cellular Sensitivity to Ionizing Radiation. Molecular and cellular pharmacology. 2013; 5:51-59.

85. Robert C, Rassool FV. HDAC inhibitors: roles of DNA damage and repair. Advances in cancer research. 2012; 116:87-129.

86. Lee JH, Choy ML, Ngo L, Foster SS, Marks PA. Histone deacetylase inhibitor induces DNA damage, which normal but not transformed cells can repair. Proceedings of the National Academy of Sciences of the United States of America. 2010; 107:14639-14644.

87. Groselj B, Sharma NL, Hamdy FC, Kerr M, Kiltie AE. Histone deacetylase inhibitors as radiosensitisers: effects on DNA damage signalling and repair. Br J Cancer. 2013; 108:748-754.

88. Botrugno OA, Robert T, Vanoli F, Foiani M, Minucci S. Molecular pathways: old drugs define new pathways: non-histone acetylation at the crossroads of the DNA damage response and autophagy. Clin Cancer Res. 2012; 18:2436-2442.

89. Yang ES, Nowsheen S, Wang T, Thotala DK, Xia F. Glycogen synthase kinase 3beta inhibition enhances repair of DNA double-strand breaks in irradiated hippocampal neurons. Neuro-oncology. 2011; 13:459-470.

90. Tai YT, Lee WY, Lee FP, Lin TJ, Shih CL, Wang JY, Chiu WT, Hung KS. Low dose of valproate improves motor function after traumatic brain injury. BioMed research international. 2014; 2014:980657.

91. Cornago M, Garcia-Alberich C, Blasco-Angulo N, Vall-Llaura N, Nager M, Herreros J, Comella JX, Sanchis D, Llovera M. Histone deacetylase inhibitors promote glioma cell death by G2 checkpoint abrogation leading to mitotic catastrophe. Cell death \& disease. 2014; 5:e1435.

92. Zhou Y, Niu J, Li S, Hou H, Xu Y, Zhang W, Jiang Y. Radioprotective effects of valproic acid, a histone deacetylase inhibitor, in the rat brain. Biomedical reports. 2015; 3:63-69.

93. Ben-Cherif W, Dridi I, Aouam K, Ben-Attia M, Reinberg A, Boughattas NA. Circadian variation of Valproic acid pharmacokinetics in mice. European journal of pharmaceutical sciences : official journal of the European Federation for Pharmaceutical Sciences. 2013; 49:468-473.

94. Nau H, Loscher W. Valproic acid: brain and plasma levels of the drug and its metabolites, anticonvulsant effects and gamma-aminobutyric acid (GABA) metabolism in the mouse. J Pharmacol Exp Ther. 1982; 220:654-659.

95. Tang W, Palaty J, Abbott FS. Time course of alphafluorinated valproic acid in mouse brain and serum and its effect on synaptosomal gamma-aminobutyric acid levels in comparison to valproic acid. J Pharmacol Exp Ther. 1997; 282:1163-1172.

96. Davis R, Peters DH, McTavish D. Valproic acid. A reappraisal of its pharmacological properties and clinical efficacy in epilepsy. Drugs. 1994; 47:332-372.

97. Cloyd JC, Remmel RP. Antiepileptic drug pharmacokinetics and interactions: impact on treatment of epilepsy. Pharmacotherapy. 2000; 20:139S-151S.

98. Bowden CL, Janicak PG, Orsulak P, Swann AC, Davis JM, Calabrese JR, Goodnick P, Small JG, Rush AJ, Kimmel SE, Risch SC, Morris DD. Relation of serum valproate concentration to response in mania. The American journal of psychiatry. 1996; 153:765-770.

99. Abadin JA, Duran JA, Sanchez A, Serrano JS. Total and free valproic acid: plasma level/dose ratio in monotherapy. Methods and findings in experimental and clinical pharmacology. 1991; 13:221-225.

100. Tomson T, Dahl ML, Kimland E. Therapeutic monitoring of antiepileptic drugs for epilepsy. The Cochrane database of systematic reviews. 2007; CD00226.

101. Gugler R, von Unruh GE. Clinical pharmacokinetics of valproic acid. Clinical pharmacokinetics. 1980; 5:67-83. 
102. Weller M, Stupp R, Wick W. Epilepsy meets cancer: when, why, and what to do about it? The Lancet Oncology. 2012; 13:e375-382.

103. Ren M, Leng Y, Jeong M, Leeds PR, Chuang DM. Valproic acid reduces brain damage induced by transient focal cerebral ischemia in rats: potential roles of histone deacetylase inhibition and heat shock protein induction. J Neurochem. 2004; 89:1358-1367.

104. Li Y, Liu B, Sailhamer EA, Yuan Z, Shults C, Velmahos GC, deMoya M, Shuja F, Butt MU, Alam HB. Cell protective mechanism of valproic acid in lethal hemorrhagic shock. Surgery. 2008; 144:217-224.

105. Ryu CH, Park KY, Kim SM, Jeong CH, Woo JS, Hou Y, Jeun SS. Valproic acid enhances anti-tumor effect of mesenchymal stem cell mediated HSV-TK gene therapy in intracranial glioma. Biochem Biophys Res Commun. 2012; 421:585-590.

106. Otsuki A, Patel A, Kasai K, Suzuki M, Kurozumi K, Chiocca EA, Saeki Y. Histone deacetylase inhibitors augment antitumor efficacy of herpes-based oncolytic viruses. Mol Ther. 2008; 16:1546-1555.

107. Gross S, Piwnica-Worms D. Real-time imaging of ligandinduced IKK activation in intact cells and in living mice. Nat Methods. 2005; 2:607-614.

108. Garbow JR, Mcintosh C, Conradi MS. Actively Decoupled Transmit-Receive Coil-Pair for Mouse Brain MRI. Concept Magn Reson B. 2008; 33B:252-259. 